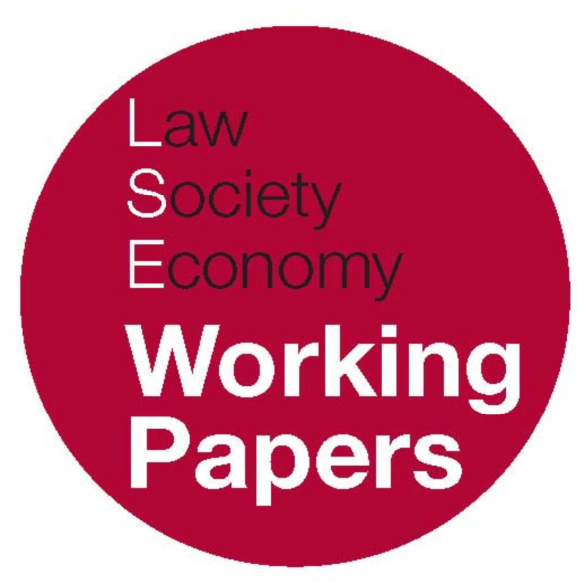

\title{
The Learning Needs of the Patent System: Implications from Institutionalism for Emerging Technologies like Synthetic Biology
}

\author{
Sivaramjani Thambisetty \\ LSE Law, Society and Economy Working Papers 18/2013 \\ London School of Economics and Political Science \\ Law Department
}

\begin{abstract}
This paper can be downloaded without charge from LSE Law, Society and Economy Working Papers at: www.lse.ac.uk/collections/law/wps/wps.htm and the Social Sciences Research Network electronic library at: http://ssrn.com/abstract $=2272980$.

(C) Sivaramjani Thambisetty. Users may download and/or print one copy to facilitate their private study or for non-commercial research. Users may not engage in further distribution of this material or use it for any profit-making activities or any other form of commercial gain.
\end{abstract}




\title{
The Learning Needs of the Patent System: Implications from Institutionalism for Emerging Technologies like Synthetic Biology
}

\author{
Sivaramjani Thambisetty ${ }^{*}$
}

\begin{abstract}
This paper transposes dominant normative critiques with an institutionalist view of patent law by analysing how the multi-institutional setup of the patent system may determine the quality and coherence of change and decision-making. The institutional environment of the patent system makes it opaque, sticky and complex. These significant features are examined for the first time in this paper. Critical opportunities for statutorily determined decision-making are best described as learning needs, expressed through heuristics such as the person skilled in the art, inventive step determinations and prior art. These learning needs, set against the broader institutional environment, severely constrain current goals and limit future decision-making possibilities. In the case of an emerging technology such as synthetic biology, the management of learning needs is likely to lead to decisional outcomes marked by a desire for short-term gains in certainty and homogeneity, rather than substantive goals.
\end{abstract}

\footnotetext{
* Lecturer in Intellectual Property Law, Law Department, London School of Economics. I am grateful to Professors Julia Black and Alain Pottage for their helpful comments. An earlier version of this paper was presented to the Nuffield Bioethics Council Working Group on Emerging Biotechnologies in March 2012; I thank the members for the feedback received there. I am also grateful to the participants at an EPSRC-funded inter-disciplinary workshop on synthetic biology LSE, 8 February 2013 for their comments on many aspects of this paper. The paper was written during a visiting fellowship at the Molecular Biophysics Division, Imperial College.
} 


\section{INTRODUCTION}

The patent system is a mix of established and newer institutions with different proclivities for change and stability. Institutions in the patent system include formal institutions, such as patent offices and courts as well as public policies that can place legally binding constraints on behaviour and possibilities. ${ }^{1}$ Legal change and decision-making refer to the processes by which the goals, rules and choices become established and evolve in the patent system. Legal change in patent law is acutely visible during periods when new, unprecedented technologies are emerging. The institutional view put forward here suggests that decision-making actors have little opportunity to construct foundational narratives; instead, legal change is constrained and directed by institutional learning needs.

The first part of the paper briefly describes dominant paradigms of evaluating the quality and coherence of patent law, before transposing these with the elements of an institutional alternative. The institutional environment of the patent system is described for the first time here as primarily opaque, sticky and complex. As a result of these features the management of uncertainty is a key preoccupation within the decision-making process ${ }^{2}$ in the patent system and is exacerbated in specific ways. Effects are seen most significantly in how institutions cope with learning needs and constraints ${ }^{3}$ that are generated in the patent system through the means of legal standards or statutory interpretation. The second part of the paper analyses heuristics such as the person skilled in the art, inventive step determinations and prior art as specific learning needs that determine decisionmaking when set against the institutional environment of the patent system. In the

1 Theorists from many fields have benefited from early institutional economists such as Douglass North and Brian Arthur. My approach is also grounded in their work, and that of subsequent theorists such as Paul Pierson and James Mahoney. See J Mahoney, 'Uses of Path Dependence in Historical Sociology' (2000) 29 Theory and Society 507; P Pierson, 'The Limits of Institutional Design: Explaining Institutional Origins and Change and Governance'; P Pierson, 'Not Just What, but When: Timing and Sequence in Political Processes' (2000) 14 Studies in American Political Development 72. Also see DC North, 'A Theory of Institutional Change and the Economic History of the Western World' in M Hechter (Ed), The Microfoundations of Macrosociology (Temple University Press 1983); WB Arthur, Increasing Returns and Path Dependence in the Economy (publisher year); DC North Institutions, Institutional Change and Economic Performance (Cambridge University Press 1990) and 'Methodological Differences between Institutional and Neoclassical Economics' in W Dugger, Underground Economics: A Decade of Institutionalist Dissent (M E Sharp 1992). An institutional view of legal change in the patent system is discussed here: $\mathrm{S}$ Thambisetty, 'Increasing Returns in the Patent System' (2007) LSE WPS 0-4. This paper also benefited greatly from the use of institutions as units of analysis in 'Methodological Differences between Institutional and Neoclassical Economics' Ch 10 in W Dugger, Underground Economics: A Decade of Institutionalist Dissent (M E Sharp 1992).

2 For instance, complex legal assessments made through nominally objective legal tests but incorporating several subjective elements through multiple steps or stages: such as the Windsurfing/Pozzoli test of inventive step and the Aerotel four-step test of patentability. Manual of Patent Practice, available at <http://www.ipo.gov.uk/practice-sec-003.pdf and http://www.ipo.gov.uk/practice-sec-001.pdf $>$ accessed 1 May 2013.

${ }^{3}$ Here the paper draws on DiMaggio and Powell's mechanisms of isomorphism. See PJ DiMaggio and W Powell, 'The Iron Cage Revisited: Institutional Isomorphism and Collective Rationality in Organizational Fields' (1983) American Sociological Review 48, 147 and D Deephouse, 'Does Isomorphism Legitimate?' (1996) Vol 39 Academy of Management Journal No: 4, 1024. 
third part this paper uses the context of an emerging technology - synthetic biology - to demonstrate how these learning needs may ultimately determine the quality and coherence of legal change in the patent system going forward. Emergence is defined here as the quality of scientific, technical and commercial uncertainty.

\section{NORMATIVE FAILURE}

There is intense exegesis in intellectual property law in an ongoing, mainly academic, attempt to further develop and refine normative positions. ${ }^{4}$ Much of the debate is determined by a puzzle centred around two potentially incommensurable ideas - the artificial scarcity of information and the generation of information. ${ }^{5}$ The patent system creates artificial scarcity in information through the grant of exclusive rights in order to incentivise the further generation of information. Generation of information, however, does not happen in a vacuum and is a function of accessibility to previously generated information. The dynamic link between scarcity and generation is a major source of legal disagreements in patent law; and legal doctrine is often a reflection of the effort to find the balance between these two utilities. ${ }^{6}$

Most recently, Robert Merges unpacks the tension between these two core ideas and how they relate to everyday legal disagreements in an attempt to unify theoretical ideas around intellectual property. ${ }^{7} \mathrm{He}$ begins by noting the foundational pluralism - both utilitarian and deontological - that lies at the heart of legitimising property rights over intellectual products. According to Merges this pluralism, coupled with maddeningly inconclusive data about whether society is better off with intellectual property rights than without such rights, gives rise to several optimising behaviours. Ideas about social utility - the purpose behind patent rights gives way to doctrinal details and discussion of the rights themselves.

${ }^{4}$ For a summary of the main normative positions see W Fisher, 'Theories of Intellectual Property', in SR Munzer, New Essays in the Legal and Political Theory of Property (publisher 2001).

${ }^{5}$ For instance while Lockean labour theory is often cited as foundational in contemporary US decisions on copyright law, it is associated with both exclusivity and individualism as well as with a more collectivist and approach to intellectual property law. In general see WJ Gordon, 'A Property Right in Self-Expression: Equality and Individualism in the Natural Law of Intellectual Property' (1993) 102 The Yale Law Journal 1533, 1540 and L Zemer, 'The Making of a New Copyright Lockean' (date) Harvard Journal of Law and Public Policy 892, 897. Damstedt also notes that Locke's main focus is '[i] n the reconciliation of strong private property rights with a common of materials available to all', BG Damstedt, Note, 'Limiting Locke: A Natural Law Justification for the Fair Use Doctrine', (2003) 112 The Yale Law Journal 1179, 1181.

${ }^{6}$ For a view of this balance as being consistently skewed in favour of property rights see M Boldrin and DK Levine, The Case Against Intellectual Property (Cambridge University Press 2008).

${ }^{7}$ R Merges Justiffing Intellectual Property (Harvard University Press 2011). A hurdle to unifying justificatory theory is disagreement as to whether justifications for intellectual property are solely utilitarian or rather a merger of utilitarian and natural law justifications. Zemer shows that Locke himself used ideas from both schools of thought. ibid. Merges' framework suggests that that there is no need to resolve any apparent schisms. 
Coping mechanisms such as 'heavily weighing the inconclusive positive data, showing IP law is necessary and efficient, discounting inconclusive data on the other side, and sometimes, 'ignoring the data altogether, or pretending that more solid data were just around the corner' are rife. ${ }^{8}$

Most significantly, the day-to-day work of intellectual property rights is carried out using mid-level operational principles, ${ }^{9}$ bypassing the need to achieve agreement on foundational values. This view of the core values underpinning patent rights (and other intellectual property rights) means that not only is it difficult to find consensus on foundational values: there is even fundamental disagreement on whether we need to refer to foundational values at all in order to settle legal disagreements. Merges says that it ought to come as a relief to be reminded that not all IP doctrines need to be designed as a precision instrument optimising overall balance. Nonetheless, many would see this view of doctrine as furthering a cull of the valid discussion of foundational values while interpreting patent statutes. ${ }^{10}$

Nonetheless, Merges captures something inherently problematic about dominant commentaries of patent law that rely on one or the other foundational idea to explicate positions. Many intractable disagreements about patentability standards are also long-standing - such as whether we ought to allow broad patents over genes as products, and whether software ought to be considered patentable technology. Dominant critiques based on normative or foundational views of how patent protection does or does not serve public interest are unable to conclusively justify or determine patentability standards going forward. ${ }^{11}$ Although normative approaches can be very illuminating about different values expressed through intellectual property rights, minus policy-based touchstones and these free-standing views amount to nothing more than 'stage-setters'12 in legal decision-making that give way to institutionalised decision-making processes. In recognition of and response to the failings of normative approaches, several recent

8 ibid, 3.

9 Efficiency, non-removal and proportionality and dignity. R Merges, Justifying Intellectual Property (n 7) (Harvard University Press 2011).

${ }^{10}$ For instance, Pila sets the theoretical and interpretational context of a central tenet of European Law the requirement of invention - in the following way: when properly construed, the invention requirement both defines categories of subject matter capable of supporting a patent, and restricts the protection conferred by a patent to individual subject matter conceived qua invention. In serving these functions, the requirement for an invention helps to fulfil the public benefit objectives of the patent system by mediating the balance struck by patents between individual patentees and the public. See J Pila, The Requirement for an Invention in Patent Law (OUP 2010).

11 These can be seen for instance in the continued controversy over patentability standards in biotechnology (Human Genome Sciences v Eli Lilly [2011] UKSC 51 where the SC followed the EPO's lead, but explicitly rejected one of the cornerstones of its approach - the specific, substantial and credible standard applied under industrial application), the scope of gene patents (C-428/08 Monsanto v Cefetra [2010] All ER (D) 65 (Jul) (ECJ) where the ECJ appeared to depart from strict liability by requiring genes to be 'expressed' in order to infringe a gene product patent) or indeed even the purpose of the patent system (Association for Molecular Pathology v USPTO 94 USPQ2d 1683 (SDNY March 29, 2010). A decision from the US SC is expected soon in the first half of 2013

12 n 7,3 . 
works have started appraising specific institutional aspects. ${ }^{13}$ So far there has been no sustained attempt to define unifying features of patent systems that can set the foundations for a macro-social view of institutional change and evolution. The next section uses examples largely from UK and European case law, and to a lesser degree US law, to venture common denominators of the institutional climate seen in most jurisdictions. ${ }^{14}$

\section{THE PATENT SYSTEM}

A patent application is a legal and technical document that describes what the inventor believes he has invented. The application is filed at the patent office tasked with examining the patent specification for patentability. Determining patentability or the meaning of patent specifications can call for complex and different kinds of information in this part of the legal system. The invention - or description of the invention ${ }^{15}$ provided by the inventor - is examined for criteria for grant such as novelty, inventive step and industrial application. Under the European Patent Convention (EPC), the invention should not solely consist of subject matter excluded from patents (like mental acts, business methods and computer programs), ${ }^{16}$ and the invention should be disclosed to the extent that an average person skilled in the art can work it.

Patent offices apply principles, standards and legal tests handed down by appellate courts. These are set out in examining manuals that are designed to convey certainty to the applicant about the probability of obtaining patent protection for his invention. Often judicial decisions are made operable as 'bright lines' - clearly defined rules or legal standards comprising objective factors - by patent offices ${ }^{17}$ even if they are not presented as such in judicial language.

${ }^{13}$ C Long, 'The PTO and the Market for Influence' (2009) 157 University of Pennsylvania Law Review 1965, 1991; L Davies, 'Technical Cooperation and the International Coordination of Patentability of Biotechnological Inventions' (2002) Vol 29 Journal of Law and Society Issue 1, 137; Peter Drahos, Does Dialogue Make a Difference? Structural Change and the Limits of Framing, 117 The Yale Law Journal POCKET PART 268 (2008) available at <http://yalelawjournal.org/2008/06/01/drahos.html> accessed 1 May 2013.

14 These features, albeit drawn from established jurisdictions, are also relevant for emerging and newly established patent systems in the developing world because these are largely modelled on older patent systems. See P Drahos, The Global Governance of Knowledge (Cambridge University Press 2010).

15 There are several limitations to the effectiveness of a literal description of functionality in a patent application, compounded at times by the unintended consequences of legal rules on disclosure. S Thambisetty, 'Sufficiency of Disclosure in the Common Law: Complexity, Divergence and Confusion' in L Bentley and others (eds), The Common Law of Intellectual Property: Essays in Honour of David Vaver (Hart Publishing 2010). Also see A Pottage and B Sherman, Figures of Invention: A History of Modern Patent Law (OUP 2010).

16 S 1(2) UK Patents Act, 1977 which reflects Art 52(2) of the European Patent Convention 1973.

${ }^{17}$ For instance, the USPTO guidelines after the SC decision in Bilski v Kappos 130 S Ct 3218 (2010) were further modified after Mayo v Prometheus 132 S Ct 1289. These guidelines provide a decision-making algorithm on patent eligibility. See $<$ http://www.uspto.gov/patents/law/exam/mayo prelim guidance.pdf > and $<$ http://www.uspto.gov/patents/law/exam/bilski guidance 27jul2010.pdf $>$ accessed 1 May 2013. 
Although patent office iterations cannot always provide precision, these bright-line rules attempt to distil the law in an algorithm based on substantive or procedural law. Patent law is thus fashioned by both administrative rule-making by patent offices and legislative or judicial law-making. ${ }^{18}$

The claims of a patent are legal statements informed by existing prior art and motivated by the desire to specify the full extent of control or ownership over the invention. Even if the invention itself appears worthy of a patent, the description of the invention has to be supported by a disclosure sufficiently detailed to allow an averagely skilled person in the field to 'work'19 the invention. Due to this requirement, interpretation of technical terms in individual patent applications is highly significant and frequently leads to expensive litigation with unpredictable outcomes. ${ }^{20}$ When interpreted by courts, meanings of words in the claims will often be explicitly 'constructed' in the context of applicable legal doctrine.

Despite the way in which patents and courts appear to work together in the patent system, there are considerable differences in decision-making processes. Courts work with established rules of legal interpretation, actively justifying and reasoning outcomes - a characteristic of the judicial process that enables methodological and substantive scrutiny. The patent office, in contrast, is an administrative agency that operates overwhelmingly on documentary evidence via internal processes that are difficult to scrutinise. The 'judges' in patent offices are technically qualified to examine patents. However, procedural expertise in legal reasoning, such as evidence sifting or weighting of arguments that may be routinely expected from judges of national courts, is rare. Yet patent law is as much a creature of patent office rules as legislative and judicial time. ${ }^{21}$ Combined with the technical content of patent law, this feature leads to exceptional cognitive heuristics that form the basis of the analytical significance of the 'emerging' nature of some technologies. The three features discussed below are developed from the

Also see K Mullally, 'Legal (Un)certainty, Legal Process and Patent Law' (2011) 42 Loyola of Los Angeles Law Review 1109 and Manual of Patent Practice UKIPO, available at $<$ http://www.ipo.gov.uk/p-manual-practice> accessed 1 May 2013.

18 P Leith, 'Judicial or Administrative Roles: The Patent Appellate System in the European Context' (2001) 1 Intellectual Property Quarterly (1) 50.

${ }^{19}$ Working an invention depends on the type of invention it is. Merrell Dow Pharmaceuticals Inc $v$ HN Norton and Co Ltd [1996] RPC 76 (HL). In general, see S Thambisetty, 'Sufficiency of Disclosure in the Common Law' (n 15), 199.

${ }^{20}$ See discussion of Kirin Amgen Inc v Hoechst Marion Roussel Ltd and Transkaryotic Therapies (No 2) [2004] UKHL 46 at [32] in S Thambisetty, 'Patents as Credence Goods' (2007) Oxford Journal of Legal Studies 27 (4) 707, 714. In US patent law uncertainty in claim construction has given rise to judicial confusion about de novo reviews at appellate level. See J Andersen and PS Menell, 'From De Novo Review to Informal Deference: An Historical, Empirical and Normative Analysis of the Standard of Appellate Review for Patent Claim Construction' (date) UC Berkeley Public Law Research Paper 2150360. Also see S Miller, 'Do Fuzzy Software Patent Boundaries Explain High Claim Construction Reversal Rates?' Available at <http://papers.ssrn.com/sol3/papers.cfm?abstract id $=2139146>$ accessed 1 May 2013.

${ }^{21} \mathrm{n} \mathrm{18.} \mathrm{Also} \mathrm{see} \mathrm{S} \mathrm{Thambisetty,} \mathrm{'Timing,} \mathrm{Change} \mathrm{and} \mathrm{Continuity} \mathrm{in} \mathrm{the} \mathrm{Patent} \mathrm{System'} \mathrm{in} \mathrm{S} \mathrm{Haunss} \mathrm{and}$ others (eds) The Politics of Intellectual Property: Contestation Over the Ownership, Use and Control of Knowledge and Information (Edward Elgar 2009). 
patent system's response to key emerging technologies of the last two decades genomic and digital technologies: theoretical ideas about how organisations work and form the processes that produce

\section{(A) OPACITY}

Opacity in patent systems comes about in different but related ways: uncertainty in the quality of patents; uncertainty in the property boundaries of individual patents; and in the commercial and technical prognosis of unprecedented technologies (that may be disruptive or creative of new industries). The quality of a patent comprises its technological value and commercial significance, 22 but a patent application tells us little about the quality of the underlying invention.

A patentable invention must pass a minimum threshold of novelty and inventiveness, but the legal test itself does not convey the degree of inventiveness or what that may mean for commercial success. ${ }^{23}$ Indeed, successful exploitation of an invention can often depend on external factors unrelated to the technical merit, such as efficient business models and the presence of supporting ancillary technologies. The inability to quantify the effect of novelty, inventive step, disclosure and breadth on a patent's economic value is exacerbated by immature markets associated with emerging technologies.

Since patents contain information in varying degrees 24 they are lumpy indicators of underlying quality, and patent counts are poor proxies for the underlying value of patents. ${ }^{25}$ Empirical studies seem to support the idea that association with scientific literature can be used as a value determinant ${ }^{26}$ by coopting peer review as a verifier of a firm's actual and potential knowledge assets. ${ }^{27}$ Breadth of a patent, represented by the various fields under which a patent may be categorised, using the four-digit International Patent Classification (IPC) system is also used as a predictor of value. ${ }^{28}$

22 D Bosworth, D Filou and M Longland, 'Measuring the "Quality" of Patents' (2003) Draft Report to the UK Patent Office, available at <http://www.patent.gov.uk/about/ippd/ipresearch/qualityofpatents.pdf> accessed 1 May 2013.

23 'When a patent examiner examines a patent application, he has very little idea of whether he is looking at the technological cutting-edge equivalent of sliced bread, or looking at one of the applications that make up the staggering statistic of inventions that are never commercially exploited'. See S Thambisetty, 'Patents as Credence Goods' (n 20) 712 (footnote omitted). Also see C Long, 'Patent Signals' (2002) 69 University of Chicago Law Review 625, 654.

24 ibid, 654

${ }^{25}$ BH Hall, A Jaffe and M Trajtenberg, 'Market Value and Patent Citations: A First Look' (2001) NBER Working Paper no. 7741, National Bureau of Economic Research, available at $<$ http://www.card.iastate.edu/research/stp/papers/hall-jaffe-trajtenberg.pdf $>$ accessed 1 May 2013.

26 M Carpenter and others, 'Linkage Between Basic Research Literature and Patents' (1980) 13(2) Research Management 30; AM Subramanian and P Soh, 'An Empirical Examination of the Science and Technology Relationship in the Biotechnology Industry' (2010) 7 Journal of Engineering and Technology Management 160.

${ }^{27}$ S Thambisetty, 'Patents as Credence Goods' (n 20).

28 J Lerner, 'The Importance of Patent Scope: An Empirical Analysis' (1994) 25 RAND Journal of Economics 319 . 
In recent years, the quality of patents has suffered from the public's perception of patent office laxity in the examination of patents. ${ }^{29}$ This has led some commentators to question the strong presumption of validity of a patent 30 and has led to measures such as 'validity opinions' at the UKIPO. ${ }^{31}$ Another aspect of patents that creates significant opacity is the difficulty in defining boundaries. Uncertainty here is a function of the difficulty in resolving whether a particular act is infringing of a patent or not. Consequently Lemley and Shapiro suggest that a patent is no guarantee of exclusion of competitors but should be conceived more precisely as a right to try to exclude. ${ }^{32}$ Based on a swathe of empirical evidence from history, law and economics, Bessen and Meurer find that the lack of predictable legal boundaries necessitates a change in institutions and laws. ${ }^{33}$ In emerging technologies, this kind of uncertainty can be exacerbated by the rapidity of technological change and the consequent evolution of meanings of technical terms in the claims that make it difficult to predict infringing acts. ${ }^{34}$

For instance, if new developments produce a new way of making a product that has already been patented, ought the patent to cover rights to this new way, even though the patent holder could not have conceived of it when making his patent application? In the US the notoriously complicated doctrine of equivalents applies. In the UK the same doctrine applies in a limited way - in the final analysis infringement is a matter of fairness to the inventor and adequate notice to third parties about the property boundaries of inventions. ${ }^{35}$ For rapidly moving technologies, such an analysis can go either way, generating considerable difficulty in assessing the true scope and value of patents in the absence of, or prior to, expensive litigation.

New technologies can also create a period of doctrinal uncertainty that can colour the way the industry regards such rights. Brad Sherman wrote in 1990 of a

${ }^{29}$ See R Merges, 'As Many as Six Impossible Patents Before Breakfast: Property Rights for Business Concepts and Patent System Reform’ (1999) 14 Berkeley Technology Law Journal 577; K Dam, 'Some Economic Considerations in the Intellectual Property Protection of Software' (1991) 24 Journal of Legal Studies 321, 369.

${ }^{30}$ S Kieff, 'Economic Perils of US Patent Reform: Flexibility's Achilles Heel' in W Pyrmont and others (eds), Patents and Technological Progress in a Globalized World (Springer 2008).

31 See empirical observations on validity opinions in S Thambisetty, 'Patent Litigation in the UK: Solutions in Search of a Problem?' (2010) European Intellectual Property Review 32(5), 238.

${ }^{32}$ M Lemley and C Shapiro, 'Probabilistic Patents' (2005) 19(2) Journal of Economic Perspectives 75.

${ }_{33} \mathrm{~J}$ Bessen and MJ Meurer, Patent Failure: How Judges, Bureaucrats and Lanyers Put Innovators at Risk (Princeton University Press 2008).

34 In an infringement action the SC in Kirin-Amgen [2004] HL 46 reversed lower court findings to invalidate the patent by defining the term 'host' cell differently.

35 Kirin-Amgen [2004] HL 46 also affirmed as a general rule of law that claims in a patent application may cover products or processes involving technology unknown at the time the claim was drafted. Although not as far-reaching as the doctrine of equivalents in US law, this rule incentivises use of generic terms and levels of abstraction, exacerbating uncertainty in emerging technologies. In software the effect of uncertain terminology is the primary cause of assertions that that patents in this entire field lack the 'notice' function that is an essential feature of property rights. See J Bessen and MJ Meurer (n 33). See also I Karet, 'Construction of Patents' in Roughton and others (eds), The Modern Law of Patents (Lexis Nexis Butterworths 2010). 
'period of openness' in interpretation in the case of biotechnology patents, especially in the context of the standard of non-obviousness. ${ }^{36}$ On a macro level it can take a few years for this period of openness to become converted to a 'closed' form of interpretation more common in law. On a micro level, it can mean patents of uncertain validity and scope. ${ }^{37}$ Both doctrinal uncertainty and intrinsic uncertainty about patent boundaries can lead to opacity expressed as difficulty in predicting the value of patents for capital and labour markets as well as the research environment. ${ }^{38}$

\section{(B) STICKY}

The patent system comprises a cluster of complementary institutions that work to a variety of decision-making norms ranging from administrative and quasi-judicial to the highest appellate courts. The implicit ways in which the behaviour of each influences the other is poorly captured by existing legislative frameworks. Patent offices are essentially administrative bodies with quasi-judicial functions. ${ }^{39}$ The European Patent Office (EPO) for all practical purposes functions as a specialist court, 40 assuming the purpose of the EPC as a given, and deals only with the prosecution and grant of patents, and post-grant validity objections. Therefore the EPO cannot take account of potential problems that may arise during infringement decisions when granting a patent. ${ }^{41}$ In Europe, national appellate courts have jurisdiction over patent infringement and often work within constitutional or public law constraints that do not apply to the EPO. Divergent opinions among such domestic appellate courts are not uncommon. The European Court of Justice (ECJ) has limited jurisdiction only in cases where the EU Biotechnology Directive is in question. ${ }^{42}$ In addition, the Japanese, European and US patent offices together form the Trilateral Office that often takes up a

\footnotetext{
36 B Sherman, 'Patent Law in a Time of Change: Non-Obviousness and Biotechnology' (1990) 10 Oxford Journal of Legal Studies 278.

${ }^{37}$ For example, a new standard of industrial application used by the UKIPO for the first time in 2005 was finally resolved in 2011 when the Supreme Court rejected the standard as not appropriate under UK law. In the interim the UKIPO has applied the standard, resulting in patents that may now be found invalid if litigated. See Human Genome Sciences (n 11). S Thambisetty, 'Legal Transplants in Patent Law: Why "Utility" is the New "Industrial Applicability" (2009) 49 Jurimetrics Journal 155.

38 See 'Patent Signals' (n 23) for alternate ways in which value can be signalled to markets.

${ }^{39}$ See at $\mathrm{n} 18$.

${ }^{40}$ The EPO is the executive body and one of two organs of the European Patent Organisation (EPOrg), the other being the Administrative Council which is a supervisory and, to a limited extent, legislative body. The power to amend the EPC lies only with the contracting states. See $<\underline{\text { http: } / / \text { www.epo.org } />}$ accessed 1 May 2013.

${ }^{41}$ This has been a source of consternation for British judges who have to adjudicate on new kinds of subject matter such as patents for new uses of the same substance, used in the same way. See observations on G2/88 MOBIL OIL/Friction Reducing Additive in Merrell Dow Pharmaceuticals Inc v H N Norton \& Co Ltd [1996] RPC 76.

42 The Directive 98/44/EC on the Legal Protection of Biotechnological Inventions [1998] OJ L213/13 (Hereafter 'Biotech Directive') has been incorporated into the implementing guidelines of the EPO. See $<$ http://www.epo.org/news-issues/issues/biotechnology.html $>$ accessed 1 May 2013.
} 
single negotiating position on behalf of the component offices in international fora such as WIPO (World Intellectual Property Organization). ${ }^{43}$

In this context, coordination and adaptive behaviour on the part of legal institutions often results in the remarkable staying power of legal doctrines and rules in the patent system. Solving problems such as optimal patent standards for new kinds of subject matter (such as inventions in emerging technologies) is resource-intense, and the temptation to rely on analogy and incremental solutions that satisfice ${ }^{44}$ can be very high.

An example is presented by the way in which guidelines prepared by the USPTO (United States Patent and Trademark Office) (1998) tackled the speculative nature of uses disclosed in patent applications for full or partial gene sequences. The guidelines specified that a valid application must include specific, credible and substantive uses for gene and protein sequences in order to be eligible for a patent. ${ }^{45}$ This particular permutation of terms had not explicitly been used before in US case law and European patent law had a different terminology - that of industrial application to be disclosed as part of a valid patent application.

For a period between 1998 and 2011, however, the specific, credible and substantial standard was successfully championed and transplanted into UK and European law through means that suggest adaptive behaviour. ${ }^{46}$ Stock markets are highly sensitive to adverse patentability signals from policy-makers and the legal system. Given the risk and resources required for creating new patentability standards for ill-understood technologies, there was, in the years subsequent to 1998, an inevitable short-term benefit to following the first formulation of a solution to a complex problem. The proliferation of the standard cannot be attributed to its optimality - in fact robust legal analysis would have demonstrated both its unsuitability under UK law - a view recently confirmed by the UK Supreme Court ${ }^{47}$ - as well as damage to the coherence of lateral legal doctrines in UK patent law. 48

The evolution of the industrial application standard in EU, UK and international patent law indicates how formal and informal interactions among patent offices appear to generate normative emulation and diffusion of legal

\footnotetext{
43 See L Davies (n 13) and P Drahos, Intellectual Property and Pharmaceutical Markets: A Nodal Governance Approach' (2004) 77 Temple Law Review.

44 Where the intention is to gain adequacy rather than fully theorised solutions, see S Thambisetty, 'Timing, Change and Continuity' (n 21).

${ }^{45}$ S Thambisetty, 'Legal Transplants in Patent Law' (n 37). The 1998 Nuffield Bioethics Council Report was one of the first to endorse the use of the SSC standard in UK law. Nuffield Bioethics Council, 'The Ethics of Patenting DNA' (1998).

46 It is now applied via bilateral US trade agreements that incorporate the standard. For instance see AUSFTA Art 17.9.

47 Human Genome Sciences v Eli Lilly and Company (n 11) [40]. The SC referred to 'significant and fairly fundamental differences' between US patent law and the EPC that made alignment of the law in this regard 'not currently practicable'.

48 S Thambisetty, 'Legal Transplants' (n 37).
} 
standards. ${ }^{49}$ Such interactions contribute to the entrenchment of epistemic communities in patent law. ${ }^{50}$ Internationally, an epistemic community acts to develop consensus regarding technical issues within their professional ambit then takes this consensus back to their national contexts, so 'increasing the likelihood of convergent state behaviour and international policy coordination'. ${ }^{51}$

What makes stickiness in the patent system an enduring institutional feature is the dearth of remedial or corrective processes that can reverse expectations accruing from an early course of action. Ideally inappropriate legal standards will be weeded out through litigation, for:

[Common] law evolves towards efficient rules because, inter alia, judges favour efficient rules, inefficient rules are litigated more often than efficient ones, litigants advocating efficient rules have greater incentives than those advocating inefficient rules to incur legal expenses that increase the likelihood of a favourable decision, and resorting to court settlement is more likely in cases in which legal rules governing the dispute are inefficient. ${ }^{52}$

This view of litigation as 'efficiency facilitator' is not supported empirically in the patent system. ${ }^{53}$ Unlike a purely private legal dispute, the economics of patents often create a grave imbalance of incentives between a patentee and a potential challenger, with repercussions not just for patent enforcement but also for the creation and continuance of appropriate legal doctrine. ${ }^{54}$

A patentee's incentive to defend his patent grossly exceeds an alleged infringer's incentive to challenge it. Where there are multiple infringers, patent invalidity judgments result in patents being turned into public goods, removing the ability of a patent attacker to exclude others from appropriating the benefits of a successful attack. ${ }^{55}$ Secondly, when multiple likely infringers compete in a product market pre-litigation, royalties are often passed through at least in part to

${ }^{49}$ S Thambisetty, 'Timing, Change and Continuity' (n 21) 221.

${ }^{50}$ As applied to international relations, epistemic communities refer to 'a network of professionals with recognised expertise and competence in a particular domain and an authoritative claim to policyrelevant knowledge within that domain of issue area'. P Haas, 'Introduction: Epistemic Communities and International Policy Coordination' (1992) International Organization 46(1) 1, 3; GG Candler, 'Epistemic Community of the Tower of Babel: Theoretical Diffusion in Public Administration' The Australian Journal of Public Administration 67(3), 294.

${ }^{51}$ Haas ibid 4.

52 O Hathaway, 'Path Dependence in the Law: The Course and Pattern of Change in a Common Law Legal System' (2001) 86(2) Iowa Law Review 601.

${ }^{53}$ JO Lanjouw and J Lerner, 'The Enforcement of Intellectual Property Rights: A Survey of the Empirical Literature' (1997) NBER Working Paper 6296.

${ }^{54} \mathrm{~S}$ Thambisetty, 'Timing, Change and Continuity' (n 21) 229.

55 In the pharmaceutical sector US laws attempt to combat this problem by granting the first generic company that challenges a brand firm's patent US law exclusivity for a period of 180 days, during which period other authorised generics are prohibited. Unfortunately, this raises incentives to collude and settle between the brand pharma and first generic company leading to unintended consequences. See M Carrier, 'Solving the Drug Settlement Problem: A Framework for Presumptive Illegality' (2009) 108 Michigan Law Review 37. Also see J Farrell and RP Merges, 'Incentives to Challenge and Defend Patents: Why Litigation Won't Reliably Fix Patent Office Errors and Why Administrative Review Might Help' (2004) 19 Berkeley Technology Law Journal 943. 
consumers downstream. Therefore there is no economic reason to expect direct infringers to challenge a patent, even if they act collectively. Losing a challenge can be a very different outcome from the alternative of uncomplainingly paying nondiscriminatory royalties, as challengers often find themselves subject to injunctions or less favourable licensing terms. Patentees can also charge differential royalties to penalise firms that do not settle early; all the above weaken the infringer's incentive to challenge in the first place. ${ }^{56}$ Further, patent litigation is inaccessible to many users (and would-be abusers) ${ }^{57}$ of the system because of eye-watering costs of litigation. Due to all of these reasons patent litigation can be a poor way to weed out sub-optimal doctrine. 58

\section{(C) INSTITUTIONAL COMPLEXITY}

Institutional complexity in the patent system is a direct result of the multiplicity of decision-making organisations, each seemingly working to different institutional logic. The divergence in logic may arise because they are applying different statutes or applying the same statute in different circumstances. In a multi-institutional patent system ${ }^{59}$ decisions are made through and influenced by a complicated feedback loop between courts, patent offices and users. Even if we assume that institutions in the patent system were designed for optimal decision-making, over time these institutions respond to their environment or strike bargains in ways that can restrict current goals or limit future possibilities. Institutional complexity in the patent system can lead in the strong version to incompatible, or in the weak version, to competing, decisional outcomes. The significance of such outcomes at least partly relates to the inability to direct the evolution of legal doctrine.

The following are three examples of ways in which decision-making can be constrained in the patent system as a result of institutional complexity. First, there are conflicts between the administrative disposition and quasi-judicial function of patent offices. A good illustration of the kind of conflict that may arise is seen in the self-perception of the EPO of its role in Diagnostic methods based on article 4(3) of the EPC which gives the EPO a mandate to grant patents. ${ }^{60}$ In this case, article 4(3) formed the basis for a very narrow reading of the exclusion of 'diagnostic methods', making it easy to patent appropriately claimed diagnostic methods. It ought not to be taken as justification to read exclusions from patentability narrowly, but rather to administer the EPC and interpret provisions in light of the statutory framework.

\footnotetext{
${ }^{56}$ Farrell and Merges ibid.

${ }^{57} \mathrm{C}$ Helmers and L McDonagh, 'Trolls at the High Court?' LSE Legal Studies Working paper no: $13 / 2012$

58 S Thambisetty, 'Patent Litigation in the UK: Solutions in Search of a Problem?' (2010) 32(5) European Intellectual Property Review 238.

59 AK Rai, 'Engaging Facts and Policy: A Multi-Institutional Approach to Patent System Reform' (2003) 103 Columbia Law Review 1035.

${ }^{60}$ Diagnostic Methods (2006), G 0001/04 OJ EPO 334
} 
Secondly, the constraints of lower specialist courts and greater decisionmaking resources available to higher generalist courts can lead to different approaches: for instance, approaches of the EPO (which is similar to a lower specialist court) and the ECJ (which has jurisdiction over patentability under the Biotechnology Directive) to article 53(a) of the EPC. The EPO cannot take matters such as competition law, the needs of the single market or European human rights jurisprudence into account, yet its decisions have great impact on such matters. The ECJ in contrast can take a more purposive approach in interpreting patentability standards. In the case of Monsanto vs Cefetra ${ }^{61}$ the ECJ relied on an innovative purposive interpretation of article 9 of the Biotechnology Directive $^{62}$ to allow the importation of soya meal into the Netherlands, even though this soya meal was 'contaminated' with a gene patented in Europe but not in Argentina where the soya meal originated. The ECJ saw the gene as present but inert, rather than being expressed, which is the function for which it was patented in the first place. This view of the scope of a gene patent is radically different from the scope of a chemical product patent that would demand strict liability for infringement. ${ }^{63}$

Thirdly, decision-making in patent law is a mix of technical and legal reasoning and unconventional norms of judicial fact-finding prevail. Patent cases in the higher appellate courts are frequently decided on the basis of 'tipping-point facts' and facts on which lower-court decisions were made could be of little relevance, even though it may be appropriate to continue to rely on the earlier decision for a rule of law. For instance, in the UK, in Actavis vs Novartis ${ }^{4}$ the patent was granted on the premise that fluvastatin was so water soluble that it was difficult to devise a sustained release formulation. Significantly, however, fluvastatin was not of such extreme water solubility, thus making the problem that the invention sought to solve illusory. This alternate finding on facts removed any basis for patentability. Similarly in Kirin Amgen Inc v Hoechst Marion Roussel Ltd and Transkaryotic Therapies (No 2)65 the decision to invalidate the highly valuable erythropoeitin patent was made by the House of Lords on a review of the technical term 'host cell'. The necessity for appellate courts to review technical facts is a feature of patent law that can lead to greater unpredictability in decisionmaking when complicated facts are in play, a feature that can constrain options available to current and future users of the patent system.

The three illustrations identified above are not exhaustive of the kind, but are indicative of the degree of the institutional complexity that can impact on the

\footnotetext{
${ }^{61}$ C-428/08 Monsanto v Cefetra [2010] All ER (D) 65 (Jul) (ECJ).

62 'The protection conferred by a patent on a product containing or consisting of genetic information shall extend to all material, save as provided in Article 5(1), in which the product is incorporated and in which the genetic information is contained and performs its function.' (Emphasis added) Directive 98/44/EC on the legal protection of biotechnological inventions OJL 213, 30/07/1998 p 0013 - 0021. 63 UKIPO Examination Manual 'Meaning of Infringement', available at < http://www.ipo.gov.uk/practice-sec-060.pdf> accessed 1 May 2013.

64 [2010] EWCA Civ 82.

65 [2004] UKHL 46.
} 
ability to make (for instance, bioethical decisions) and revise (for instance, on the legal requirement of 'invention') decisions. They provide insight into processes of decision-making that can lead to incoherent outcomes through the design of individual institutions, and inter-institutional linkages. ${ }^{66}$

\section{(D) DECISION-MAKING UNDER INSTITUTIONAL COMPLEXITY}

Institutional complexity creates specific constraints on decision-making. When a decision has to be made under uncertainty, the result is a push for rationality in ways that do not necessarily lead to better decision-making. An overview demonstrates the possibility of incoherence and highly instrumental reasoning. Two specific aspects of decision-making in patent law in the UK and Europe stand out due to different dispositions of multiple decision-making institutions. The first is in the interpretation of the 'technical requirement' and the second within bioethical decision-making.

\section{(i) 'Technical' as patentable}

The legal requirement of 'technical' in UK and European law to identify patentable inventions that combine explicitly excluded subject matter with patentable technical applications, is one example where institutional complexity has prevented the judicial realignment of an incoherent doctrine. There are four categories of subject matter that are not 'inventions' as per article 52(1) of the EPC and section 1(2) of the UK Patents Act. The EPO settled on the absence of 'technical' character as justification for all of the exclusions. If a subject matter has technical character, it is an invention capable of supporting a patent, although there is no requirement for the 'technical' feature to dominate. ${ }^{67}$ This approach to the requirement of 'invention' allows the EPO and national courts, who are obliged to harmonise practice with it, to avoid having to positively define each category or each listed subject matter and focus instead on identifying 'technical' aspects that would allow a mixed invention to escape the exclusion.

\footnotetext{
66 Legal indeterminacy is a related notion that has been discussed by several scholars. However, indeterminacy can imply a normative basis, which 'incoherency' attempts to avoid. On indeterminacy in patent law see SJ Plager, 'Challenges for Intellectual Property Law in the Twenty-First Century: Indeterminacy and Other Problems’ (2001) University of Illinois Law Review 69 (Discussing indeterminacy in practice and procedures in patent systems); G Mandel, 'The Non-Obvious Problem: How the Indeterminate Non-obviousness Standard Produces Excessive Grants' (The non-obviousness standard is $[\ldots]$ both too high and too low. It is indeterminate) 57-128. PM Janicke, 'On the Causes of Unpredictability of Federal Circuit Decisions in Patent Cases' (2005) 3 Northwestern Journal of Technology and Intellectual Property 93 (examining breadth and generality of the patent statutes as sources of unpredictability in patent law). K Mullally, 'Legal (Un)certainty, Legal Process, and Patent Law' (n 17).

${ }^{67}$ For a summary see L Bently and B Sherman, Intellectual Property Law (Oxford University Press 2008), $410-430$.
} 
This approach has several drawbacks. The concept of 'technical' has proven to be highly malleable and increasingly both banal artefacts ${ }^{68}$ and progressively ephemeral internal workings of a computer have both been held to have 'technical' character. ${ }^{69}$ At its best the legal test aims to attain certainty by relying on technical characterisations; at worst it squeezes out legitimate spaces for policy-based reasoning in patent law. ${ }^{70}$ EPO cases were summarised in the UK CA as supporting six mutually contradictory approaches to 'invention', including one described as 'not intellectually honest'. Despite these strongly expressed opinions on the merits of 'technical' character as a legal test it has been very difficult to begin the process of reforming the standard largely as a result of the multiinstitutional setup in Europe.

While post-grant issues of validity and infringement remain the exclusive jurisdiction of national courts, the EPO drives interpretation on pre-grant patentability, making conflicting applications of the law between national courts as well as between those courts and the EPO difficult to escape. In the UK, although decisions of the EPO are not strictly binding, they are of 'great persuasive authority', derived from their 'expert court status' and because it would be 'highly undesirable for the provisions of the EPC to be construed differently in the EPO from the way in which they are interpreted in the national courts of a contracting state'. ${ }^{71}$

The European Economic and Social Committee's saw the technical character test as indefinable and opening the way to the abolition of exclusions; and its attempted inclusion in the now failed Directive on Software patentability termed a 'de facto acceptance and justification of the a posteriori drift of EPO jurisprudence'. ${ }^{72}$ Pila concludes that the doctrinal and theoretical incoherence of the EPO's approach to the invention requirement should lead to the demise of 'judiciary-driven legal development' within the EPO, agreeing with the Enlarged Board of Appeal of the EPO that 'it is time for the legislator to take over'. ${ }^{73}$ In the absence of a credible and representative legislative authority in Europe that can

${ }^{68}$ For instance, the art of writing (a method) is made technical through the use of pen and paper. Case T258/03 Auction Method/Hitachi,.

${ }^{69}$ Case T-0935/97 (IBM/Computer Programs).

70 As a response to this claim the UK CA attempted to reframe unpatentable subject matter listed in s 1(2) of the UK Patents Act as positive categories of non-inventions in a bid to move away from overly narrow interpretations that regard them purely as exceptions to the rule of patentability (Aerotel Ltd $v$ Telco Holdings Ltd (and others) and Macrossan's Application [2006] EWCA Civ 1371). This followed the UK High Court's attempt, for the same reasons, to a reclassify each of the listed subject matter as soft and hard exclusions that support a spectrum of nuanced policy and purpose-based interpretations (CFPH's Application [2005] EWHC 1589 (Pat)).

71 Merrell Dow Pharmaceuticals Inc v HB Norton \& Co Ltd [1995] UKHL 14, [12].

72 They also saw it as legal casuistry. Opinion of the Economic and Social Committee on the Proposal for a Directive of the European Parliament and of the Council on the patentability of computerimplemented inventions' [2003] OJ C61/154, as cited in J Pila, 'Software Patents, Separation of Powers and Failed Syllogisms: A Cornucopia from the Enlarged Board of Appeal of the Patent Office (2011) 70(1) Cambridge Law Journal 203.

73 Pila ibid referring to the Enlarged Board of Appeal's decision in G_0003/08 (PRESIDENT'S REFERENCE/Computer Program Exclusion) [2010] EPOR 36 [7.2.7] fn 150, 
take over, the task will inevitably fall to the new European Patents Court due to start functioning in $2014 .{ }^{74}$

\section{(ii) Bioethical decision-making}

Ethical questions often touch upon other laws such as human rights law, international obligations on scientific risk and safety, and human dignity. ${ }^{75}$ The space for broad-based reasoning in patent statutes tends to be limited and consequently ethical provisions in patent law come under great pressure to fulfil several different kinds of demands. ${ }^{76}$ Higher appellate courts that are generalist in nature have recourse to a greater variety of approaches to a legal problem, and are more likely to adopt a 'purposive' approach to interpretation. ${ }^{77}$ Such courts may also identify issues that are best left to legislatures. In contrast, specialist agencies such as patent offices can be expected to take the purpose of a statute as given and proceed to address legal questions as a matter of literal or semantic interpretation. ${ }^{78}$

Patent law in Europe is dominated by the EPO, which functions as a specialist 'court' despite also being an administrative body with a corporate structure geared towards customer service (to actual and potential patent holders).

74 This court too presents several challenges in the form of legal and institutional heterogeneity across national jurisdictions in Europe, and the need for common procedure to reconcile dramatically different structures and cultures of patent litigation in Europe. The UK Parliament House of Commons European Scrutiny Committee has recently concluded that the Unified Patent Court is likely to hinder rather than help the enforcement of patents in the European Union. See House of Commons European Scrutiny Committee, 'The Unified Patent Court: Help or Hindrance?' 25 April 2012.

75 'The biotech directive is divided into recitals and articles, which are the only enforceable part of the Directive. However, given the legislative history of the directive, the recitals provide more than just context to the articles, although not all recitals match up to articles. R Gold and A Gallochat, "The European Biotech Directive: Past as Prologue' (2001) European Law Journal 7(3), 331.

${ }^{76}$ In its 1998 report the Nuffield Council chose to report on patentability of DNA as an 'ethical issue'. The question of the ownership of DNA sequences can certainly be considered an entirely ethical question in the same sense as all ownership, use and exploitation of property for profit could be. Legally, however, the ethical question is limited to specific provisions called into question infrequently. 'The Ethics of Patenting DNA' ( $\mathrm{n}$ 45). The EPO countenances the use of art 53(a) EPC only in 'rare and exceptional' circumstances. Howard Florey/Relaxin [1995] EPOR 541 (EPO (Opposition Division)).

${ }^{77}$ In purposive interpretation, the text's 'purpose' is the criterion for establishing which of the semantic meanings yields the legal meaning. For more see A Barak, Purposive Interpretation in Law (Princeton University Press 2011).

78 The influence of institutional capacities on legal interpretation, particularly in the case of complex legislation like patent statutes, is worth exploring further. See CR Sunstein and A Vermeule 'Institutions and Interpretation', available at < http://www.law.uchicago.edu/files/files/156.crsav.interpretation.pdf $>$ accessed 1 May 2013. A unique contrast in approach can be observed in the case of the patentability of the genetically-modified oncomouse at the European Patent Office, a specialist body and the Canadian Supreme Court, a generalist appellate body. For a discussion see S Thambisetty, 'The Institutional Nature of the Patent System and its Impact on Bioethical Decision-Making', in C Lenk, N Hoppe and R Andorno (eds), Studies in the Legal, Ethical and Political Impact of Intellectual Property (Ashgate Publishing House 2007) 247. 
In the past the EPO has cast its role as one of granting patents ${ }^{79}$ and has generally interpreted exclusions to patentability narrowly in a growing body of case law. ${ }^{80}$

In this context, two recent decisions on stem cells provide an interesting demonstration of institutional complexity in Europe. Biotechnology is unusual in that the EPO uses the Biotechnology Directive (which is a European Union document, unlike the EPC, which predates the European Union) as a supplement to the interpretation of the EPC. Consequently the involvement of the ECJ - an appellate court with broad jurisdiction, provides the possibility of a broad-based ethics approach ${ }^{81}$ to patentability only in the case of biotechnological inventions.

In the WARF case, the Enlarged Board of Appeal of the EPO ${ }^{82}$ had to decide whether stem cells developed by destroying the human embryo from which they are derived could be patented. Patentability here rests on the correct interpretation of a rule that applies the general prohibition against the patenting of immoral inventions embodied in article 53(a). The rule reads:

[Under] Article 53(a), European patents shall not be granted in respect of biotechnological inventions which in particular, concern the following [...] 'uses of human embryos for industrial or commercial purposes'. .83

The EPO had to interpret whether 'uses' of human embryos included the destruction of them. The EPO found that:

Rule 28(c) [...] EPC forbids the patenting of claims directed to products which - as described in the application [emphasis added] - at the filing date could be prepared exclusively by a method which necessarily involved the destruction of the human embryos from which the said products are derived, even if the said method is not part of the claims. ${ }^{84}$

This interpretation allows the EPO to limit the exclusion to those stem cells that involved destruction of a human embryo initially. If further production does not require such destruction then, arguably, patentability is not excluded by the

\footnotetext{
79 As per the EPO's reading of art 4(3) EPC in G 1/04 Diagnostic Methods 2006 OJ EPO 334.

80 The EPO claims there is no such general rule to read exclusions narrowly. But see L Bently and others, 'Exclusions from Patentability and Exceptions and Limitations to Patentees' Rights' WIPO Standing Committee on the Law of Patents SCP 15/3.

81 A possibility that can lead to assertions of judicial activism. See A Arnull, Judicial Activism and the Court of Justice: How Should Academics Respond?' , available at http://papers.ssrn.com/sol3/papers.cfm?abstract id=1986817 accessed 1 May 2013.

82 G-2/06: Use of embryos/WARF (2009) OJ EPO 306.

83 Rule 28(c) Convention on the Grant of European Patents (European Patent Convention). Art 53(a) of the EPC states that European patents shall not be granted in respect of: (a) inventions the publication or exploitation of which would be contrary to 'ordre public' or morality, provided that the exploitation shall not be deemed to be so contrary merely because it is prohibited by law or regulation in some or all of the Contracting States.

${ }^{84}$ Use of Human Embryos/WARF (n 82) 331.
} 
wording above. In effect the EPO has pointed out how to circumvent an exclusion..$^{85}$

This apparent guide to circumvention of an explicit exclusion is in fact a tried-and-tested method whereby exclusions from patentability are reduced to linguistic silos that can be side-stepped by avoiding or specifying certain terms in patent applications. At least three instances come to mind. The EPC excludes animal varieties from patentability, but the narrow interpretation of the term by the EPO means that genetically modified animals may be patented. Applicants have only to ensure that the term 'animal variety' is not used in the application. ${ }^{86}$ Similarly, computer programs explicitly excluded in the EPC may be patented so long as the patent description incorporates 'technical' components as banal as servers or other general-purpose equipment. ${ }^{87}$ Thirdly most 'diagnostic methods' are now patentable provided at least one step in the process of diagnosis is practised away from the human or animal body, which can be readily incorporated into the description of the diagnostic method invention. 88

As a decision-making heuristic these examples direct the EPO away from the plurality of values underlying the patent system towards a kind of rationality that relies on certainty even if it is the wrong kind of certainty. They may also be viewed as a result of institutionally taking the purpose of a statute as a given - that is to grant patents. Any provision that derogates from it is therefore read narrowly.

The decision of the generalist ECJ in Brustle $v$ Greenpeace $e^{89}$ also concerned patentability of an invention that presupposes a process entailing the destruction of the human embryo. The argument that the absence of any reference to the prior destruction of human embryos in the patent application would mean that products of such embryos are patentable was explicitly addressed by the court and rejected:

Not to include in the scope of the exclusion from patentability set out in Article 6(2)(c) of the Directive technical teaching claimed, on the ground that it does not refer to the use, implying their prior destruction, of human embryos would make the provision concerned redundant by allowing a patent applicant to avoid its application by skilful drafting of the claim..$^{90}$

The ultimate basis for the ECJ's decision rested on excluding patentability where respect for human dignity could be affected. ${ }^{91}$

\footnotetext{
$85 \mathrm{~S}$ Stercx and J Cockbain, 'Assessing the Morality of the Commercial Exploitation of Inventions Concerning Uses of Human Embryos and the Relevance of Moral Complicity: Comments on the EPO's WARF Decision' (2010) 7(1) SCRIPTed 92.

86 Case T-315/03 Harvard/Transgenic animal [2005] EPOR 31 (EPO (Technical Board of Appeal)).

${ }^{87}$ Case T-258/03 Hitachil automatic auction method [2004] OJ EPO.

${ }^{88}$ G 1/04 Diagnostic Methods (n 60).

89 Oliver Brustle v Greenpeace C-34/10.

90 ibid 50.

91 ibid 34.
} 
It is valuable to note the different constraints and proclivities enforced by different institutional settings - the ECJ as a general appellate court is able to take a broad-based view of the implications of the case whereas the EPO as a specialist court is restricted to the confines of a self-selected set of constraints that aim for certainty. In both developments there appear to be a push towards a kind of rationality that appears to value certainty over substance.

\section{(E) The Analytical SignificanCe Of OpaCity, Stickiness AND INSTITUTIONAL COMPLEXITY}

Institutional features of the patent system can constrain the ability to cope with complexity and uncertainty, leading to adaptive mechanisms. It takes time and resources to learn new things, and learning often involves trial and error. People are more likely to do something that many others are also doing and may adapt their own behaviour based on what they expect other people to do. ${ }^{92}$ Learning effects (where knowledge gained in the operation of a complex system leads to higher returns from continuing use), coordination effects (when the benefits received from choosing a particular standard increase as others adopt the same option) and adaptive expectation (derived from the self-fulfilling character of certain kinds of expectations) may all arise. ${ }^{93}$

It has also been argued that actors who operate in complex and opaque contexts are heavily biased in the way they filter information into existing 'mental maps', ${ }^{44}$ where confirming information tends to be incorporated and disconfirming information tends to be filtered out. This places disproportionate importance on early events that may go on to have a decisive impact on the substantive content of legal doctrine, not because it is the best or most appropriate standard but because it came first. The discussion and examples in this section demonstrate that given the risks of formulating law under new and complex technological circumstances learning behaviour, adaptive expectations, satisficing and the development of mental maps are all likely to manifest regularly in the patent system. ${ }^{95}$

92 These ideas first grew out of the social acceptance of technology as stated by DC North, Institutions, Institutional Change and Economic Performance (Cambridge University Press 1990); BW Arthur, Increasing Returns and Path Dependence in the Economy (University of Michigan Press 1994) and 'Competing Technologies, Increasing Returns, and Lock-in by Historical Events' (1989) Economic Journal 99116. While much of sociological institutionalism discusses convergence rather than diverging institutional development, from observation the literature on convergence appears most relevant to patent law. The most obvious reason driving institutional homogeneity is the rapid harmonisation of international legal standards and processes that mostly overrides territorial and historical specificities. For a useful critique of convergence frameworks see J Beckert, 'Institutional Isomorphism Revisited: Convergence and Divergence in Institutional Change' (2010) 28(2) Sociological Theory 150.

93 Pierson effectively builds on Arthur and North's work in the context of political institutions. See 'Timing, Change and Continuity in the Patent System' (n 21).

94 A Denzau and DC North, 'Shared Mental Models: Ideologies and Institutions' (1994) 47(1) Kyklos 3.

95 P Pierson, 'Increasing Returns, Path Dependence and the Study of Politics' (2000) 94(2) American Political Science Review 251, 259. See discussion of this paper in 'Timing, Change and Continuity' (n 21) and 'Legal Transplants' (n 37). 
Relatedly, the force of ideas may function at times as an independent variable. ${ }^{96}$ In patent law, however, theoretical discussions about ideational processes and change are scarce. ${ }^{97}$ An example of a policy paradigm ${ }^{98}$ or directional idea that has emerged is 'expansion' - in types of subject matter that can be protected and in scope and strength of such rights. This idea shifts the burden of justification from why property rights should be granted to explanations of why a particular subject matter should be denied patent protection (on grounds of not being inventive ${ }^{99}$ or being inadequately disclosed, ${ }^{100}$ for instance). In the context of emergence, such directional ideas may impose assumptions that foreclose opportunities to learn and define problems outside of such ideational paradigms.

Collectively, these processes are likely to result in isomorphism, where adaptive outcomes become the goal, rather than improving efficiency or performance.101 A consideration of DiMaggio and Powell's mechanisms of institutional isomorphic change suggests mimetic processes and socialisation (such as through transnational networks of diffusion) ${ }^{102}$ are the main drivers of isomorphism. ${ }^{103}$ One obvious example of a driver of isomorphism in international intellectual property law is seen in the TRIPS Agreement, where countries are obliged to implement 'normal' tests for patentability criteria such as novelty, inventive step and industrial application. ${ }^{104}$ To achieve 'normality' then is to achieve legitimacy. Mimesis itself becomes a key benchmark. Provisions such as section 3(d) of the Indian Patent Act defy the norm and are therefore considered illegitimate, ${ }^{105}$ although this provision can be justified on the basis of other,

96 Historical institutionalism is most receptive to the study of ideational processes. See D Beland, 'Ideas and Social Policy: An Institutionalism Perspective' (2005) Vol 39 Social Policy and Administration no: 1 February, 1 (in the context of the welfare state).

97 A good example of such scholarship is John Duffy's account of the adoption of non-obviousness as a central tenet of patentability that also richly describes the process of legal change. J Duffy, 'Inventing Invention: A Case Study of Legal Innovation', available at <http://www.utexas.edu/law/conferences/ip/DuffyPaper.pdf> accessed 1 May 2013.

98 Defined by Beland as the 'structured intellectual background of policy decisions' (n 96).

99 An approach adopted by the EPO towards computer-implemented inventions. (See discussion below).

100 Often in gene or protein function where insufficient disclosure impacts on patentability due to lack of industrial application. Art 5(3) Biotech Directive.

101 PJ DiMaggio and W Powell, 'The Iron Cage Revisited: Institutional Isomorphism and Collective Rationality in Organizational Fields' (1983) American Sociological Review 48, 147. A fuller treatment of the subject would require a study of the specific drivers of change in the patent system including the desire for uniformity in IP regimes demanded by global business and the link of patent standards to international trade rules.

102 See J True and M Mintrom, 'Transnational Networks and Policy Diffusion: The Case of Gender mainstreaming’ (2001) International Studies Quarterly 45, 27.

103 DiMaggio and Powell identify coercive isomorphism, mimetic processes and normative pressures as three mechanisms of institutional change (n 101).

104 R Dreyfuss, 'TRIPS and Essential Medicines: Must One Size Fit All? Making the WTO Responsive to the Global Health Crisis', in Pogge, M Rimmer and Rubenstein (eds), Incentives for Global Public Health: Patent Law and Access to Essential Medicines (Cambridge University Press 2010).

105 The 2013 USTR Special 301 report which criticises a recent decision of the Indian SC upholding the validity of this provision. See < http://www.ustr.gov/sites/default/files/05012013\%202013\%20Special $\% 20301 \% 20$ Report.pdf $>$ 
explicitly stated objectives of the TRIPs Agreement and its purposive interpretation in light of India's own legal history. ${ }^{106}$

An example of socialisation ${ }^{107}$ as a mechanism driving legal change is the establishment of the 'Trilateral Office' in 1983 - an entity comprising the European, US and Japanese patent offices, sharing expertise through working groups and study reports. ${ }^{108}$ The Trilateral Office even takes common positions in international negotiations such as those related to the WIPO's Substantive Patent Law Treaty. ${ }^{109}$ Loss of diversity and learning autonomy in order to reconcile all the implicit and explicit interests represented by this institutional cluster is to be expected.

In the next part of this paper I argue that the demands of decision-making in the patent system generate a constant need to manage complexity and information through learning needs. Specific decision-making heuristics such as the person skilled in the art, inventive step, prior art and bioethical decision-making are used to manage the complexity and a variety of reasoning in the patent system. As these learning needs are exercised in a context of opacity, stickiness and institutional complexity, the cognitive heuristics that express these learning needs provide further insight into the evolutionary direction of patent law. The analysis of learning needs when contextualised by the institutional features of the patent system shows that the dominant mode of legal change in the patent system is mechanical rather than normative, more laden with constraints than purposive and vulnerable to pioneering ideational directions and agenda-setting.

\section{EMERGENCE AND LEARNING NEEDS}

The demands of decision-making in the face of technical complexity and uncertainty are defined collectively here as the learning needs of the patent system. Learning needs encompass the numerous tasks, processes and skills that go into determining the terms, sometimes conflicting, that need to be met when responding to new incidents. Learning needs arise from the statutory design of patent law and therefore are applicable to all technology sectors. They are, however, more acutely expressed in the context of emerging technologies since the technology cycle is at an early stage and incomplete information prevails. In this

accessed 1 May 2013 22. The report puts India on a blacklist due to Novartis $v$ UOI, available at $<$ http://judis.nic.in/supremecourt/imgs1.aspx?filename=40212 > accessed 1 May 2013.

106 K Shadlen, 'Learning from India? A New Approach to Secondary Pharmaceutical Patents', available at <http://blogs.lse.ac.uk/indiaatlse/2013/05/03/a-new-approach-to-pharmaceutical-patents/> accessed 1 May 2013.

107 Normative pressures brought about by professions, here by the creation of inter-organisational networks spanning organisations. DiMaggio and Powell (n 101).

108 See < http://www.trilateral.net/index.html > accessed 1 May 2012. Also see Louise Davies, 'Technical Cooperation and the International Coordination' (n 13).

109 The WIPO's Standing Committee on the Law of Patents (SCP) continues to work on a draft Treaty, see < http://www.wipo.int/patent-law/en/harmonization.htm> accessed 1 May 2013. 
section, although 'emergence' is defined as a feature of new or unprecedented technologies, clearly all technology sectors were 'emerging' at a given point in time. Yet institutional growth and evolution in patent systems in the last two to three decades has been remarkable ${ }^{110}$ and this is what sets the institutional context for a contemporary understanding of emergence as a function of learning needs.

Any technology marked by scientific and technical uncertainty as well as incompletely specified commercial prognosis is an 'emerging' biotechnology for the patent system. What is 'emerging' about the technologies is greater information about scientific viability, technical possibilities and commercial implications. Legally, coping with emergence may require us to keep invention and innovation together ${ }^{111}$ for the innovative climate in an emerging technology impacts on cognitive heuristics in patent law. For instance, the inventive step test in the UK is now firmly regarded as a multi-factorial test capable of reflecting commercial considerations, most visible in the reformulation of the 'obvious to try' test. ${ }^{112}$ Similarly, disclosure requirements as a basis for validity in patents often reflect the credibility of scientific claims in the field. ${ }^{113}$

In emerging technologies each new piece of information or understanding may have unpredictable outcomes: altering existing perceptions of knowledge; making something that was previously thought impossible, reasonable to try; ${ }^{114}$ or even opening up or exacerbating gaps in knowledge. Here incomplete or evolving technical knowledge combined with the institutional characteristics of the patent system result in a complex environment that amplifies the difficulty in meeting learning needs. In this context of uncertainty the cognitive tools used by the patent system to manage complexity will determine the direction of patent law.

${ }^{110}$ For instance, R Dreyfuss and G Dinwoodie, 'Enhancing Global Innovation Policy: The Role of WIPO and its Conventions, in C Correa (ed), Interpreting the TRIPS Agreement (Edward Elgar Publishing 2010); P Drahos, Governance of Global Knowledge (n 14).

${ }^{111^{\circ}}$ The discovery of an invention and its transformation into the corresponding innovation are economically and sociologically, two entirely different things', JA Schumpeter, Business Cycles - A Theoretical, Historical and Statistical Analysis of the Capitalist Process (McGraw-Hill Book Company 1939). 85. Innovation in an emerging technology is made up of invention, opportunity and need which then can lead to differences in the rate and direction of progress of innovation or seeding of further inventions. See P Spiridon and P Clipa, 'Innovation: Variation on the Same Topic' (6 October 2010), available at < http://dx.doi.org/10.2139/ssrn.1688527> accessed 1 May 2013.

112 See P England and S Parker, 'Obviousness in the New European Order' (2012) Journal of Intellectual Property Law \& Practice 7(11), 805-815 concluding that 'long-felt need' was frequently key to inventiveness findings.

113 Scientific acceptance of homology of sequences between related species means that inventors can often reliably disclose an invention based on information disclosed for a different species. UKIPO Examination Guidelines Relating to Biotechnological Inventions, available at <http://www.ipo.gov.uk/biotech.pdf [34]> accessed 1 May 2013.

114 A typical scenario when assessing inventive step as a legal requirement of patentability (or inventive activity' which is the term used in the German and French texts) Genentech Inc's Patent [1989] RPC 147 [275]. 


\section{(A) Person Skilled in the Art}

The legal standard of the person skilled in the art (PSA) captures technological specificities. It is a fact-based formula that maximises legal certainty with discretionary spaces to achieve the purported aims of patent law. Conventionally this notional person is presumed to be skilled at repetitive processes that produce expected results. The more skill the PSA is deemed to have the less information a patentee has to disclose but the more difficult it becomes to be inventive enough to warrant a patent.

Resolving the level of 'ordinary skill in the art' in UK and US law reveals a two-dimensional aspect - what the PSA knows and how he behaves. What the PSA knows is based on the common general knowledge in the field which is different from the state of the art. ${ }^{115} \mathrm{~A}$ second dimension refers to the creative attributes and prejudices of the average PSA - a mixed question of law and fact that is governed by the rate and direction of progress in a technology. If a technology is less prone to technological revision a PSA may be subject to prejudices that constrain his creativity. 116

A particularly good example of a situation where both dimensions are called into play is where there is a claim of technical prejudice. Patentees frequently seek to defend their inventions from a charge of non-inventiveness by arguing that even if the skilled person might conceive of the invention he would reject the idea because he would believe it would not work for some reason. These 'technical prejudice' arguments, however, can only work in the UK if the information disclosed in the patent would enable the skilled person to overcome the prejudice. ${ }^{117}$

Often the PSA is portrayed as 'cautious' - one who ponders every experimental move against the backdrop of what is known in the field. He would neither go against an established prejudice nor try to enter into 'sacrosanct' or unpredictable areas nor take incalculable risks. ${ }^{118}$ Yet this caution must not be mistaken for reluctance or opposition to scientific progress in the form of minor adjustments and tweaks. Courts use experts in the field to educate them about the

\footnotetext{
115 Wheatley v Drillsafe [2001] RPC 7. For instance, a PSA is not expected to have knowledge of all patents in his field (comprising the state of the art) - but only those that a notional PSA would take for granted. Angiotech Pharmaceuticals v Conor Medsystems, 2008 UKHL 49. In the case of technology sectors populated by large corporations with well-organised R\&D units, the degree of information circulating can skew notions of common knowledge Beloit v V almet (No.2) [1997] RPC 489 per Aldous LJ.

116 For instance, it was said that using bags in vacuum cleaners had become de rigueur and therefore a matter of technical prejudice among average persons skilled in the art. Dyson v Hoover (2002) RPC 465.

117 '[p]atentability [in the face of a technical prejudice] is justified because the prior idea which was thought not to work must, as a piece of prior art, be taken as it would be understood by the person skilled in the art. He will read it with the prejudice of such a person. So that which forms part of the state of the art really consists of two things in combination, the idea and the prejudice that it would not work or be impractical. A patentee who contributes something new by showing that contrary to the mistaken prejudice, the idea will work or is practical has shown something new. He has shown that an apparent "lion in the path" is merely a paper tiger. Then his contribution is novel and non-obvious and he deserves a patent.' Pozzoli SpA v BDMO SA and Moulage Industriel de Perseigne SA (2006) EWHC 1398 (Pat).

118 Genentech and others (Expression in yeast) OJ EPO. 1995, 684 (T-0455/91) [5.1.33].
} 
PSA. The analysis is often historical, as it takes several years from the date of a patent application for it to find its way to the courts - creating further cognitive complexity.

There are at least three points about the manner in which the notional PSA is used in patent law that are directly relevant to learning needs in emerging technologies. First, early perceptions about the capabilities of the average person in the field can become precepts that are applied as rules of law in specific contexts. Such cognitive closure based, by definition, on immature technical knowledge, can potentially impact entire fields of technology due to stickiness and institutional complexity.

For instance, many biotechnology molecular products are products obtained by entering known information into a known process. ${ }^{119}$ In US law structural dissimilarity between gene sequences and the protein sequences they code for can deem one or the other of them novel and inventive even though we now know that a PSA can decode one from the other. This technological misconception has worked in favour of inventors and increased the patenting of genomic inventions (which has consequently reduced their incentive to litigate the ruling). ${ }^{120}$

Conversely, a misconception that has worked against inventors in US patent law required full structural description of gene sequences even where the molecule may have been described functionally or via the method used to obtain it. ${ }^{121}$ US courts believed that the degeneracy in genetic sequences did not allow the PSA to reliably isolate the target sequence despite well-known methods that had an established likelihood of success. Only in 2001, after a few cases had been tried and tested in higher appellate courts, did the US patent office begin to accept 'functional characteristics when coupled with a known or disclosed correlation between function and structure'. ${ }^{122}$

Secondly, the level of skill of a notionally skilled person is proportional to the maturity of a new technological field and yet can be difficult to fathom due to technical opacity. He has the skill to adapt and change but not to exercise inventive ingenuity 'which would be wrong in principle'.123 In emerging technologies with high degrees of unpredictability and relatively small numbers of scientists or research groups, demarcating routine experiments from inventiveness

119 Conceptualised by Ducor as 'translation inventions'. P Ducor, Patenting the Recombinant Products of Biotechnology and Other Molecules (Kluwer Law International 1998).

120 As noted by the National Research Council Committee on Intellectual Property Rights in Genomic and Protein Innovation, Reaping the Benefits of Genomic and Proteomic Research (National Academies Press 2006), 86.

${ }^{21}$ D Burk and M Lemley, 'Biotechnology's Uncertainty Principle' in S Kieff (ed), Perspectives on the Properties of the Human Genome Project (Academic Press 2003) 305.

122 USPTO, 'Guidelines for Examination of Patent Applications Under 35 USC 112, 1, "Written Description" Requirement' (Jan 5 2001) 66 Fed Reg 1099 1104, 1106. Note that in the interim period all patent applications will have continued to be tested against the technological misconception.

${ }^{123}$ Mölnlycke Health Care AB v Brightwake Ltd [2011] EWHC 376 (Pat). 
can be complicated given the average profile of a researcher/PSA.124 Similar concerns led the EPO in the early 1990s to observe that a skilled person in the field of genetic engineering in 1978 was not to be seen as a Nobel Prize laureate but as a graduate scientist or a team of scientists of that skill researching in laboratories that worked from molecular genetics to genetic engineering techniques. ${ }^{125}$ Ordinarily, in an emerging field a lower level of skill of the PSA would open up greater possibilities for commercial exploitation. As technology matures the PSA will accumulate more common general knowledge making it harder to get patents. ${ }^{126}$

Thirdly, since the introduction of biotechnology it has been recognised that the PSA may comprise a multi-disciplinary team rather than a single individual.127 Fuzzy boundaries of team composition can lead to unreal levels of skill, complicating the use of the PSA heuristic. For instance, while a normal PSA may be expected to consider the state of the art not just in his field, but also in neighbouring or related fields, in UK/European law, if a problem prompts the PSA to seek a solution in another technical field, the assessment of whether the solution was inventive must be based on the knowledge and ability of the skilled person from that other field. ${ }^{128}$

Team composition can also fluctuate depending on the problem at hand. In Mölnlycke a key question was whether a person familiar with coating silicone was part of the skilled team that routinely adapted wound dressings. In a decision that appears circular the court held that although a team concerned with wound dressings in general would not include a silicone specialist, the team would immediately seek and acquire such a specialist at the point they 'wanted to seriously contemplate employing silicone for the technical problem at hand'. ${ }^{129}$

Describing the average PSA and delineating what he knows or how he behaves can be a complex task given the institutional features of the patent system and accelerating change in an emerging technology. Yet this is one of the most fundamental learning needs in the patent system that influences standards of novelty, inventiveness, disclosure and infringement. Ideally, the PSA and through it, legal standards such as inventiveness, should be constantly scrutinised to reflect the gains made in a field. However, institutional features in the patent system, particularly complexity and stickiness, constrain this learning need.

\footnotetext{
124 The legal evolution of the attributes of the PSA at least in US law, may have resulted in unreal levels of 'averageness' that commentators have identified as bordering on ingenuity. J Darrow, 'The Neglected Dimension of Patent Law's PHOSITA Standard' (2009) 23(1) Harvard Journal of Law and Technology 227.

${ }^{125}$ Case T-0060/89 Harvard/Fusion Proteins (1992) OJ EPO 268.

126 In synthetic biology modularity has allowed graduate scientists to be fêted as innovators via highly publicised events like the iGEM. For a discussion of modularity and its implications see Alain Pottage, 'Too Much Ownership: Bio-prospecting in the Age of Synthetic Biology' (2006) 1 Biosocieties 1137 , 146. The iGEM is the International Genetically Engineered Machine Competition, available at

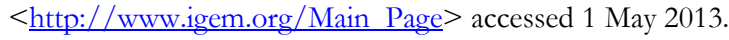

127 Genentech (n 114). Manual of Patent Practice, available at <http://www.ipo.gov.uk/practice-sec003.pdf $>$ accessed 1 May 2013.

128 Trilateral Comparative Study Report (2008) Inventive Step.

${ }^{129}$ Mölnlycke (n 123) [54].
} 
Misconceptions about technology are likely to persist and lead to cognitive closure through learning needs, and corrective measures difficult to apply via litigation.

\section{(B) INVENTIVE STEP}

'Inventiveness' is the technological distance between what existed before and the invention. It is often evaluated as what is not patentable rather than what is patentable. The reverse 'defining the precise degree of ingenuity $[\ldots]$ that is requisite to endow an invention with patentable subject matter'130 is probably impossible. As a legal test it internalises a multitude of decisions that are taken in order to manage the promise and risk of scientific enquiry. Scientific unpredictability or uncertainty can work in favour of the inventor, as they indicate that technical challenges have been overcome, making it easier to establish patentability.

Identification of the prior art is an important first step in the process of comparing the invention with the technological knowledge that existed before that invention. Factors such as the motive to find a solution to the problem the patent addresses, number, extent and ease of research possibilities, the effort involved in pursuing them, expectation of success ${ }^{131}$ and the credibility of scientific claims can all be investigated by the law through the inventive step standard.

Within UK law, inventive step, is subject to multiple variations of the main question - how inventive is inventive enough? - a question that is answered from the point of view of the person skilled in the art. This ensures that the inventive step standard is tied into the knowledge and dispositions prevailing in a particular technological field. Inventive step standard is thus a de facto way to operationalise patent law and make it technology-specific.

Both computer-implemented technologies and genomics have come under criticism for being alternatively too high and too low. ${ }^{132}$ One way to understand claims that the inventiveness threshold has been misjudged is to understand how this learning need may come to be used in an instrumental manner without enhancing the ability to improve the overall quality of decisions made in patent law. The discussion below illustrates one such instrumental use.

\footnotetext{
130 Swan Committee 1946-47 [127] as cited in A Monotti, 'Divergent Approaches in Defining the Appropriate Level of Inventiveness in Patent Law' in CW Ng and others (eds), The Common Law of Intellectual Property (Hart Publishers 2010) 177, 179.

131 Generics UK v Daiichi Pharmacentical Co Ltd [2008] EWHC 2413 (Pat).

132 See H Moir, 'How High is the Inventive Step? Some Empirical Evidence' (2009) Centre for the Governance of Knowledge and Development Working Paper, available at

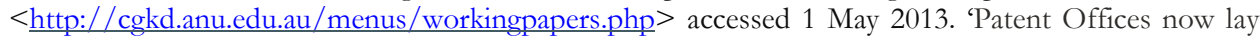
emphasis on the standard requirement of inventive step (non-obviousness) as the requirement which will do most to retain genetic patenting within acceptable bounds [...] With the growth of bioinformatics techniques to achieve automated comparison of gene functions between different species, it becomes increasingly difficult to characterise the work as anything other than routine.' W Cornish, M Llewelyn and M Adcock, 'Intellectual Property Rights (IPRs) and Genetics' (2003) 32 Report for the Department of Health UK.
} 
Inventive step is a criterion of patentability that is different from evaluating whether specific kinds of subject matter should be eligible for a patent. The question of what ought to be patentable requires a purposive understanding of why certain inventions are excluded from patentability in the first place, and links back to the plurality in foundational values. ${ }^{133}$ As a learning need, co-opting the inventive step heuristic allows the EPO to bypass difficult normative or purposive questions and seek legitimacy from the certainty of a formulaic test. This shift is suggestive of DiMaggio and Powell's description of efforts to achieve rationality under uncertainty and constraint. In the following example the inventive step standard is co-opted into the patent eligibility question. ${ }^{134}$

The principal claim in this patent is directed to a five-step method of determining the genotype at a locus within genetic material obtained from a biological sample. In step A the genetic material produces a reaction value; steps B to $\mathrm{E}$ are mental activities performed, based on the application of mathematical methods. The core of the invention as claimed by the patentee is about establishing a set of probability distributions, and applying the reaction value to each pertinent probability distribution and determining the genotype based on this data.

Generally, when there is a mix of 'technical' features (step A, because of the use of genetic material) and 'non-technical' features (steps B to E as they are mental activities), the invention is considered to be 'technical' as per the threshold bar of the EPO.135 Once the threshold patentability question is summarily considered and answered in the affirmative, the analysis then moves on to the question of inventive step. If non-technical features interact with technical features they can also be considered when evaluating the 'inventiveness' of an invention. Thus here the crucial question is whether the mathematical methods provide a 'tangible technical result' because they are central to determining the genotype of the biological sample, or whether they are just too general to provide any technical contribution beyond a trivial one. ${ }^{136}$

Based on these facts, the TBA (Technical Board of Appeal) decided that the mathematical reasoning, starting from an actual experimental value and ending with the determination of a precise genotype, was not described in sufficient detail. Part of the process employs software called GetGenos, specifically developed by the inventors and which had not been reasonably described. The mathematical methods taken on their own, therefore, made no sense. The PSA would not know how to proceed from step A to step E, which means there is no interaction between the 'technical' and 'non-technical' aspects of the invention leading to a 'tangible technical result'. Hence the mental activities of steps B to E

\footnotetext{
133 See L Bentley and others (n 80) and discussion above on the requirement for an invention.

134 Case T-0784/06 Beckman Coulter Inc. v Roche Diagnostics GmbH [2010 (EPO (Technical Board of Appeal)).

135 See <http://www.epo.org/law-practice/legal-texts/html/caselaw/2010/e/clr_i_c 3 2 8 .htm> accessed 1 May 2013 for a discussion of EPO case law.

136 n $134,14$.
} 
are to be disregarded in assessing inventive step. This leaves step $\mathrm{A}-\mathrm{a}$ process that already exists in the prior art and is therefore unpatentable.

It ought to have been possible for the EPO, based on the wording of article 52(2) of the EPC to exclude this particular invention as consisting largely of mental processes and/or mathematical methods, both of which are explicitly excluded as non-patentable inventions. Instead, the choice of inventive step standard allowed the EPO to refer to an objective heuristic rather than rely on a purposive approach to justifying the exclusion of this computer-implemented invention from patentability. The use of inventive step to deny patentability maximises the EPO's legitimacy with more observers and stakeholders than might otherwise be the case. This sort of operationalisation or search for rationality runs the risk of 'patentability by creep' where incremental changes to learning needs could lead to questionable standards of patent eligibility. 137

\section{(C) PrIOR ART}

The type of prior art cited in patent applications can often be an indication of the level of uncertainty and constraints under which patent offices are making decisions.

Between pioneering inventions, inventions in emerging technologies and trivial advances lies a swathe of inventions that are differentiated by the type and quantum of prior art cited. Biotechnology patent applications have shown a higher-than-average number of citations to non-patent references (NPR) suggesting proximity to basic research and an absence of technical advances to build on. ${ }^{138}$ A recent study of biotechnology firms found that on average a patent in this sector cites $18 \mathrm{NPR}$, a majority of which are scientific publications. ${ }^{139}$

Historically, patent offices have struggled with technologies that come from unprecedented backgrounds due to the difficulty in collating prior art. When the patent office 'examines' patents it tends to rely on previously granted patents, pending applications and scientific journals or other technical materials. There is a bias towards documented prior art, although clearly science and technology

\footnotetext{
${ }^{137}$ In the case of genomic inventions the threshold question of patent eligibility for genes gave way to the industrial application or utility assessment. See 'Legal Transplants' (n 45).

138 On average, international patents reference 15 per cent NPR. For the period 1990-2004 about 55 per cent of citations in biotechnology-related international patents were to NPR OECD Patent Statistics Manual (OECD Publishing 2009) 117. An important patent on protein logic gates, for example, references only seven scientific publications, none earlier than 2001 and no patent references: US Patent US7604805B2 2009-10-20 Protein Logic Gates. Other examples include WO201115337 Methods and systems for simulations of complex biological networks using gene expression indexing in computational models (2011, 0 NPR, 0 PR), EP1848815B1 Esterases for Monitoring Protein Biosynthesis in vitro (2010, 11 NPR, 2 PR), US2011009772 In vivo gene sensors (2011, 101 NPR, 5 PR), US2010009871 Devices and Systems for the Creation of DNA Cluster Arrays (2010, 0 NPR and 0 PR). Elsewhere I use the term 'immature technologies' 'Patents as Credence Goods' (n 20).

139 AM Subramanian and P Soh (n 26) 165.
} 
interactions are not limited to these. 'Informal, non-traceable flows of tacit knowledge' do not figure in patent office examinations. ${ }^{140}$

With software-implemented inventions information tends to be embodied in the programs written or the inventions that the programs actualise, making it hard to identify prior art against which future patent applications can be tested. ${ }^{141}$ Further 'de-skilling' of programming meant diffusion of the technology which further exacerbated the difficulty in gaining access to documented prior art for patent offices in the 1980s and 1990s. ${ }^{142}$

Conservative patent offices, that rely only on formally documented prior art, risk granting patents that ought not to be granted, which in turn can further entrench notions of average skill in the art and related legal standards. It could be argued that it is the desire to retain familiar objectivity that leads patent offices to discount unconventional sources or forms of knowledge.

Cognitive closure and an inability to correct it here is more likely because of the institutional features of the patent system. For instance, in conventional biotechnology the availability of vast quantities of genomic data in the public domain has been slow to filter through to the patent office. Chin notes that this is because patent offices invoked a model of DNA discovery that insists on explicit structural formulae for specific nucleic acid molecules whereas genetic research literature often reports on advances that apply to general classes of nucleic acids. ${ }^{143}$ The misreading results in significant discrepancies in how prior art is used as a learning need by the patent system and the scientific community's understanding of the state of the art. Given the institutional features described so far, in the case of unprecedented technologies that have unusual means of generating and disseminating knowledge, prior art exercised as a learning need is likely to be directed towards certainty rather than accuracy.

\section{SYNTHETIC BIOLOGY AS AN EMERGING TECHNOLOGY}

Part I describes the institutional features of the patent system and part II demonstrates inherent learning needs within patent frameworks where

$140 \mathrm{~J}$ Callaert and others, 'Traces of Prior Art: An Analysis of Non-Patent References Found in Patent Documents' (2006) 69(1) Scientometrics 3.

${ }^{141}$ J Park, 'Evolution of Industry Knowledge in the Public Domain: Prior Art Searching for Software Patents' (2005) 2:1 SCRIPTed 47.

142 The grant of the Amazon 1-click patent was widely criticised as an instance of the USPTO missing prior art that, though undocumented, was widely known in the field among programmers. Former Amazon.com developer Barton-Davis stated that it was just one example of the way in which the company has benefited enormously from ideas circulating in the open and/or free software world of the middle 1990s: '1-click is a simple, logical and obvious use of the cookie system pioneered by Netscape and others.' SL Jarvenpaa and EH Tiller, 'Protecting Internet Business Methods: Amazon.com and the 1-click Checkout', available at

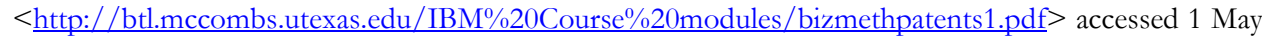
2013.

143 A Chin, 'Artful Prior Art and the Quality of DNA Patents' (2006) 57 Alabama Law Review 57975. 
institutional features constrain the ability to make decisions. Part III analyses synthetic biology as an emerging technology in order to primarily predict how the learning needs in the patent system may play out going forward. Relatedly, the discussion also considers how we may improve the mechanics of patent law without necessarily committing to normative positions on patentability standards.

In this section, five related and non-exhaustive features of synthetic biology that are likely to determine the future management of legal complexity are identified. These features are potential pressure points in the management of uncertainty given the learning needs in the patent system.

Synthetic biology has been described as a new engineering discipline ${ }^{144}$ and one that requires an unprecedented level of collaboration and coordination between disciplines. It is described as bringing together opposite but symmetrical scientific cultures - the 'deconstruction of life', where biological systems are dissected in the search for simplified and minimal forms, and the 'construction of life', where the goal is to build systems inspired by general biological principles and to reproduce the behaviour of live systems. ${ }^{145}$

\section{(A) INTEgRALly MULTI-DisciplinaRY}

Biology has benefited greatly from paradigms derived from artificial intelligence in silica modelling and digital circuitry and this is being actively played out in synthetic biology. For example, the field of nanoscale biocoordination polymers ${ }^{146}$ brings nanotechnology to synthetic biology. Artificial gene circuits are to be embedded into microbial cells that function as switches, timers, oscillators, and Boolean logic gates. Understanding complicated networks such as cellular phenomena that arise from the interactions of genes with proteins, and the processes that make cells operate reliably in diverse conditions are fundamental issues The idea is to separate complicated networks into many simpler ones that resemble the modules of gene regulation. Building more complex systems from

144 E Andrianantoandro and others, 'Synthetic Biology: New Engineering Rules for an Emerging Discipline' (2006) Molecular Systems Biology 1.

145 V de Lorenzo, L Serrano and A Valencia, 'Synthetic Biology: Challenges Ahead' (2006) 22 (2) Bioinformatics 127. Broadly, the field comprises four different approaches. The bottom-up approach focuses on reconstruction of chemically synthesised genomes after they have been fully sequenced. The reconstructions can take place in sets that are then put together. Metabolic engineering looks at ways of modifying metabolic pathways - a path that holds considerable promise including the possibility of producing biofuels in viable commercial forms. The development of ideal cell chassis that produce desirable responses to bacterial DNA currently focuses on neutral minimal cells. In the near future different versions and strains may be pre-developed for specific applications. The fourth approach is to focus on parts, devices and systems where modularity, characterisation and standardisation are key challenges. This systemic approach to design aims to produce systems and networks that perform tasks and accurately reproduce same part for same function. Prof. Kitney, Prof. Kitney Imperial College Lectures on 'Synthetic and Systems Biology' January 2012..

146 See H Liu and L Tang, 'Nanoscale Biocoordination Polymers: Novel Materials from an Old Topic' (2012) 18 Chemistry, where construction of nanoscale biocoordination polymers through replacement of synthetic organic molecules with natural biomolecules as building blocks is proposed. 
these basic gene circuit components is a key goal for biologic circuits design even though the in silica modelling is said currently to remain unstable and uncertain. ${ }^{147}$

The reliance on digital technologies has the potential to bring together the worst aspects of legal controversies in patenting biotechnology and computer programs - a possibility in synthetic biology that Rai and Boyle describe as the 'perfect storm'.148 In a situation of unprecedented complexity, and as per the framework presented, we can expect learning needs and constraints to play out in a mechanistic fashion moving towards what is generally accepted as 'legitimate' in patent law. Maximising certainty even if it leads to incoherence on a larger scale and mimicking early legal standards in related jurisdictions is a distinct possibility. Consequently, a window of opportunity to direct the law is also opened up for powerful agenda-setters. ${ }^{149}$

Integral multi-disciplinarity in synthetic biology also sets up the legal problem of delineating the PSA - what does he know and how does he behave? Given the levels of unpredictability in synthetic biology, is he more tolerant of risk and uncertainty than can be expected in other fields? Must we expect the early synthetic biologist to make unpredictable research decisions? How fluid is the team of scientists that almost certainly will make up the PSA in synthetic biology?

Given what we now understand about institutional constraints in managing the learning needs in patent law, it is worth considering how we may strengthen existing institutional mechanisms. For instance, attitudes in peer review inform the 'credibility' of scientific claims made in litigation, particularly through the characteristics and behaviour of the PSA. A reflexive archival function from scientific journals would perhaps capture more of the tacit, informal information flows that currently go undetected due to the way prior art is recognised. Are journals reporting advances in synthetic biology more tolerant of unpredictability and instability in experimental results? Whether they are more open to conceptual analysis to fill in gaps in knowledge than in other fields, and what this might mean for the PSA standard in ten years' time ${ }^{150}$ are potentially useful questions to ask.

\section{(B) De-SKILLING}

Standardisation within biological networks and systems, where successful, will allow those with limited expertise to put modules together once they have been predictably characterised. It is often stated that the key end point of synthetic

147 BS Chen and others, 'Robust Design of Biological Circuits: Evolutionary Systems Biology Approach' (2011) Journal of Biomedicine and Biotechnology doi:10.1155/2011/304236.

148 AK Rai and J Boyle, 'Synthetic Biology: Caught Between Property Rights, the Public Domain and the Commons' (2007) 5(3) PLoS Biology 389.

149 See for instance P Pierson, Politics in Time: History, Institutions and Social Analysis (Princeton University Press 2004).

150 The strongest indications thus far that institutional reform of prior art is necessary comes from Arti Rai's analysis of prior art, unit 1631, at the USPTO. This unit specifically looks at bioinformatics which has allowed a far higher success rate in denying patent applications to trivial advances than in software for instance. AK Rai, 'Let's Tame Software Patent Claims: Lessons from Bioinformatics', available at <http://www.wired.com/opinion/2012/11/software-patents-bioinformatics/ > accessed 1 May 2013. 
biology is industrial application. ${ }^{151}$ One of the methods required to arrive at successful applications is the mastery of modularity of parts and devices. Unpredictability and problems in scaling-up remain. Prof. Kitney describes this effort as akin to moving from laborious processes for the production of elegant Chippendale furniture to the industrial production of IKEA pieces, involving at its core a process of de-skilling. ${ }^{152}$ While only limited creativity may be possible with a given IKEA piece the elegance derives from the process of standardisation itself and the management of unpredictability involved.

Analogous to the open-source software effort, modular technologies may be made available through open access or open-source. The former will only allow usage of a standardised part whereas the latter will support future innovations, as it involves the disclosure of the internal workings of the part. Using the IKEA furniture analogy open access would provide only the right amount of nuts and screws and panels with a highly ordered set of instructions. Open-source will provide multiple versions of different components like multiple kinds of hinges and provide avenues for producing something different from what is laid out in the instruction sheet.

Both of these scenarios open up the possibility of innovative behaviour to almost everyone who can order components online, akin to software programming in the 1980s. Location of experimentation and innovation is likely to be diffused, with the result that prior art will be difficult to locate or document. ${ }^{153}$ Like the early computing machines, prior art may end up embedded within the innovations themselves, much like programming code. This levelling out of expertise could impact on several aspects of learning needs in the patent system because of the person skilled in the art and the central role it plays within inventive step and disclosure standards. It will become much more difficult to match the patent offices' precept with the real-world average skill that exists amongst contemporary technologists. Computing and conventional biotechnology both tell us that, unless addressed proactively, misconceptions about notional standards of skill can become entrenched because of institutional aspects and overwhelmingly direct future legal doctrine.

\section{(C) ShaRING INNOVATION Platforms AND NoRmS}

Synthetic and systems biology is populated by a number of platforms where information is shared by users and contributors to improve upon innovations and

\footnotetext{
151 Prof. Kitney Imperial College Lectures on 'Synthetic and Systems Biology’ January 2012. 152 ibid

153 This is both the fear and promise of synthetic biology. For instance, see < http://biohack.sourceforge.net/> accessed 1 May 2013 and G Bennett and others. 'From Synthetic Biology to Biohacking: Are we Prepared?' (2009) Nature Biotechnology 27, 1109.
} 
to find technical solutions and fixes to bugs. ${ }^{154}$ These platforms are web-based and powered by accelerating functionality on the Internet. Given the history of the open-source movement it may seem obvious to share bioinformatics tools, but platforms and databases in synthetic biology go beyond software-driven information to include wetware. ${ }^{155}$ The main motivation for such sharing appears to be to reduce transaction costs for downstream research ${ }^{156}$ and to collaborate to develop innovation.

Standards ${ }^{157}$ are the result of the recognition of the practical value of choosing to do the same task in the same way and are a crucial part of supporting infrastructure in a technical field. The synthetic biology community recognises this need as being key to industrial applications. ${ }^{158}$ Explicitly modelled on the process used by the Internet Engineering Task Force to support and publish the development of Internet Protocol Standards, one effort led by the BioBrick Foundation borrows the 'Request for Comments' (RFCs) mode. The original RFCs suggested Internet protocols were never intended to be finished products but deliberately exposed internal architecture to make it easy for subsequent innovators. ${ }^{159}$

However, the mimicking of standard-setting on the Internet can potentially differ in at least three significant ways that will likely impact on learning needs in synthetic biology. In 1968, when the first RFC was written, there was no financial incentive to control Internet protocols through patents. Early pioneers of the Internet were steeped in a hacker culture that existed in federally funded labs in the US and were motivated by the communal enterprise of producing knowledge. ${ }^{160}$ Synthetic biology on the contrary is a creature of the patent age. Rai notes the role of secrecy in biomedical research. ${ }^{161}$ This is partly because the publication or credit model is very strong in biology and limits motivations to share information. Collaborative models here, therefore, go against the norm, raising the potential need for public support. Thirdly, over the years the community that contributes to Internet protocols has built up strong reputational

154 These platforms are at the cutting edge of how synthetic biology is unfolding. See $<$ http://gow.epsrc.ac.uk/NGBOViewGrant.aspx?GrantRef=EP/J02175X/1> accessed 1 May 2013.

155 See for instance, <http://openwetware.org/wiki/Main Page> accessed 1 May 2013.

156 Similar to the impetus behind publicly available genomic databases. See RP Merges, 'A New Dynamism in the Public Domain' (2004) 71 University of Chicago Law Review 203 and T Caulfield, 'Open Science versus Commercialization: A Modern Research Conflict' Genome Med 2012 4(2) 17.

157 'Towards Standards in Synthetic Biology: An Exploratory Workshop of the EU-US Task Force on Biotechnology Research' (Segovia, June 2010).

158 A technical introduction to the challenges of standard-setting is provided by A Arkin, 'Setting the Standard in Synthetic Biology' (2008) 26 Nature Biotechnology 771.

159 S Croker, 'How the Internet Got Its Rules' New York Times (New York: 6 April 2009), available at < http://www.nytimes.com/2009/04/07/opinion/07crocker.html? r=1> accessed 1 May 2013.

160 AK Rai, 'Open and Collaborative Research: A New Model for Biomedicine' (2005) 131, available at $<$ http://scholarship.law.duke.edu/faculty scholarship/882> accessed 1 May 2013. Also see D Kellogg, 'Towards a Post-Academic Science Policy: Scientific Communication and Collapse of the Mertonian Norms' (2006) International Journal of Communications Law and Policy 1.

161 AK Rai, 'Open Source Biology: The Role of Law' Duke University 2/17/2005, available at

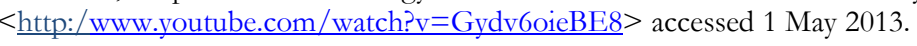


incentives to do so. Unless similar norms develop in biology, shared innovation platforms are unlikely to succeed. ${ }^{162}$

Shared innovation platforms can exacerbate the problem of locating prior art, unless they are recognised and decipherable as depositories of technical information. Additionally, as shared platforms presume a strong bioinformatics element, it may become difficult to locate inventions that have been disclosed in a different technical context, unless the patent office has an 'across the board' way of searching for it. In the case of nanotechnology-enabled inventions a solution was found in specifying a new international classification number ${ }^{163}$ that would enable searching for prior art across several previously unrelated fields. As a tool to manage complexity such action requires concerted effort internationally.

\section{(D) Proprietary AND NON-Proprietary INFORMATION}

Leading open-science initiatives such as the BioBricks Foundation, the iGEM competition and the BioConductor project, which seeks to 'collaboratively create extensive software for computational biology and bioinformatics', have received considerable attention from both scientists ${ }^{164}$ and social science commentators. ${ }^{165}$ In contrast to both the extreme version of the copyleft movement ${ }^{166}$ and conventional biology, synthetic biology brings together proprietary and nonproprietary parts, processes and information. User-driven innovation creates multiple end points for the proliferation of exclusive intellectual property rights because legal frameworks currently governing open data and innovation in synthetic biology do not appear to have a viral element to them. For example, the Registry of Standard Biological Parts (partsregistry.org) does not oblige users who take the parts and make other devices with the parts or subject it to modifications to make their creations available on the same open basis:

The BPA [BioBricks Public Agreement] is a scaleable contract among parties, not a copyright-based license $[\ldots]$ the BPA is a contract between one person

\footnotetext{
162 In biology this would require contributions to standard-setting and integration technologies to be supported by research councils, the tenure process and universities, as valuable knowledge contributions that evidence skill and calibre.

163 In general see L Leydesdorff, 'Patent Classifications as Indicators of Intellectual Organisation' Journal of the American Society for Information Science and Technology, available at $<$ http://arxiv.org/pdf/0911.1439.pdf $>$ accessed 1 May 2013. Also see J Paradise, 'Claiming Nanotechnology: Improving USPTO Efforts at Classification of Emerging Nano-Enabled Pharmaceutical Technologies', availbale <http://papers.ssrn.com/sol3/papers.cfm?abstract id=1949877> accessed 1 May 2013.

164 B Canton and others, 'Refinement and Standardization of Synthetic Biological Parts and Devices Nature Biotechnology' (2008) 26(7) 787.

$165 \mathrm{~J}$ Zhang, C Marris and N Rose, 'The Transnational Governance of Synthetic Biology: Scientific Uncertainty, Cross-Borderness and the "Art" of Governance' (2011) BIOS Working Paper 41.

166 Copyleft is a general method for making a program (or other work) free, and requiring all modified and extended versions of the program to be free as well available at $\langle\underline{\mathrm{http}}: / / \mathrm{www}$.gnu.org/copyleft/ $>$ accessed 1 May 2013.
} 
who wants to make a genetically encoded function free to use and someone else who wants to use it freely. As a second major difference between the BPA and the GPL [General Public License], there is no required 'give back' or 'viral' clause in the BPA. ${ }^{167}$

This hybrid openness does not preserve the open model for second- or thirdgeneration biological parts or applications. Additionally, some technologies and processes have been made available in two different versions: the 'for profit' proprietary version and the 'for sharing' open version. For instance, Tom Knight's BioBricks - a technology for stitching and assembling sequences - was redesigned by him for industrial applications. The proprietary version can assemble up to ten parts in a single reaction while the non-proprietary one could only link three. ${ }^{168}$

Open-source biology also has several implications for the evaluation of inventive step standards in the US and UK/Europe. First, by making some and not other information openly available, platforms such as BioFab, the BioBrick Foundation and BioConductor are in effect making it harder to get patents that encompass basic technology but easier to develop more sophisticated technologies and processes. This will, whether by design or inadvertence, preserve patentability of subsequent generations of biological inventions but raise the threshold bar of inventiveness. In effect it amounts to a 'spoiler' strategy of publishing patentdefeating prior art that is not uncommon in patent law. ${ }^{169}$

The second related point is that the spoiler strategy will only work if patent examiners are aware of what is transpiring in the field. The non-exclusive nature of the open strategy will mean an inevitable spread of prior art in unconventional locales such as sophisticated web-based infrastructures or embedded within a highly engaged global community of synthetic biologists from multiple disciplines. This spread of prior art can project problems with software programming code and genomic information to several degrees of complexity due to the range of technologies involved. Patent examiners trained perhaps in conventional biotechnology or computing may not be able to access information available in open or hybrid platforms in an unconventional format.

There are other extrinsic reasons why an open strategy may appeal to synthetic biologists. There is now clear evidence of exclusionary behaviour among scientists, of withholding scientific data for either money or competition. ${ }^{170}$ This problem of access has led to sustained efforts in the US to 'minimize exclusionary behaviour by requiring scientists and research institutions to put data and certain

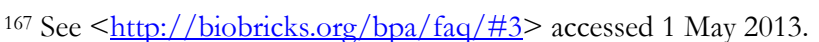

${ }_{168}$ M Baker, 'The Next Step for the Synthetic Genome' (2011) 473 Nature 473403.

${ }^{169}$ S Baker and C Mezzetti, 'Disclosure as a Strategy in the Patent Race' (2005) 48 Journal of Law and Economics 173; G Parchamovsky, 'Publish or Perish' (2000) 98 Michigan Law Review 926.

$170 \mathrm{~J}$ Walsh, 'For Money or Glory? Secrecy, Competition and Commercialization in Science' (2004) Presentation at American Sociological Association, cited in Rai (n 160) endnote 29. 
types of research tools into the public domain or at a minimum license them widely and non-exclusively for a reasonably fee'. ${ }^{171}$

At least in the US, as a result of the way the Bayh Dole Act is applied by universities, scientists are severely restricted in making use of intellectual property that has been produced in employment, ${ }^{172}$ unless that intellectual product was non-exclusive in the first place. Contributing to public platforms allows scientists to take the information with them if they move from one university to another, or even to a private firm. ${ }^{173}$ Other commentators have also noted that the excitement with which open-source biology is being received is largely because it is seen as solving the problem of access to intellectual goods that we have seen develop in biotechnology. ${ }^{174}$

The interpretation of 'private' as 'non-public' clearly has a direct impact on public databases as well as innovation platforms under both open-access and open-source constraints. The legal resolution of this issue may be more difficult if that public disclosure results in or leads to profit (to establish employability or to seek commercial funding, for instance). Additionally, in the UK inventions made under an employment contract are owned by the employer; and the terms of the employment can evolve and extend beyond the contract of employment itself. This includes inventions even, arguably, in cases where the invention may not be patentable. ${ }^{175}$ Potentially this could encompass information such as pure computer programs or raw biological discoveries, which are not to be regarded as inventions. Consequently the mixing of open, common and private information in synthetic biology is likely to lead to some of the gravest problems of managing uncertainty and learning needs in the patent system.

171 AK Rai (n 160). Arti Rai notes a number of initiatives such as National Research Council Sharing Publication-Related Data and Materials: Responsibilities of Authorship in the Life Sciences (Washington: National Academies Press, 2003); NIH, 'Principles and Guidelines for Recipients of NIH Research Grants and Contracts on Obtaining and Disseminating Biomedical Research Resources: Final Notice' (1999) Federal Register 64.

172 Madey v Duke 307 F 3d 1351 (Fed Cir 2002).

173 In the UK too there is considerable uncertainty about the true scope of the research use exception even in the case of publicly funded universities, as they are increasingly conducting research in collaboration with private concerns. Such research cannot therefore be regarded as 'non-commercial'. Gower's review pointed out that the additional requirement that research be 'private' (interpreted as 'non-public') in order for the exception to apply, is problematic. There is 'concern that if research has to be "non-public" to be exempt then publicly funded research that is, as a condition of funding, disclosed may not also qualify for the research exception' Gower's Review of Intellectual Property (November 2006) 46.

${ }^{174}$ K Nolan-Steveaux, 'Open Source Biology: A Means to Address the Access and Research Gaps?' available at <http://www.chtlj.org/sites/default/files/media/articles/v023/v023.i2.Nolan-

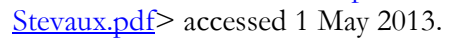

175 This controversial point was alluded to but not fully resolved in LIFFE Administration and Management $v$ Pavel Pinkava [2007] RPC 30 [89]. 


\section{(E) UNPREDICTABILITY AND RISK}

Although there are claims that synthetic biology has grown exponentially in the last few years, the field has many fundamental macro-level problems as well as micro 'bugs'.176 Some of the mismatch between contemporary promissory narratives and the actual scientific progress being made is about the natural unpredictability of science; some of it is about inflated claims in synthetic biology that do not work; and yet other aspects appear to indicate a truly unpredictable field.

Does unpredictability in synthetic biology go over and beyond 'normal' risks in experimentation? For example, we are told that few synthetic biologists work with more than ten genes at a time. ${ }^{177}$ Keasling's achievement in making a precursor of artemisinin using a dozen or so genes from multiple species is undercut by the (to some) disproportionate time and expense involved. ${ }^{178}$ Another example is the use of BioBrick-type methods - a process that allows desirable parts or nucleotides to be 'stitched' together. But reactions are currently less successful with longer molecules, discouraging long assemblies. When it comes to designing new genomes, computational models are not as good as they are at modelling existing genomes. As more genes are brought into the system, uncertainty goes up exponentially, and modelling fails. ${ }^{179}$ Synthetic biologists appear to be caught up in a laborious process of trial and error, unlike more predictable aspects of modern engineering disciplines. ${ }^{180}$

On an industry-wide level, a major question for synthetic biology is the credibility with which in silica modelling can be transposed to genetic material. Are the bioinformatics tools that define the genetic material more important than the material itself? If not, then with what specificity can we claim to predict biological processes and systems, particularly when they are scaled up? Engineerisation is largely about standardisation, but biological systems and processes are predictably unpredictable.

In the UK, the current requirements for enabling disclosure are not particularly taxing. ${ }^{181}$ The teaching in a patent application on how to make an invention work is in fact not used to assess inventiveness. Instead, all that is required to fulfil the inventive step requirement is that the invention will plausibly work, based on the contents of the patent specification. ${ }^{182}$ Given the unpredictability in synthetic biology, it may be legitimate for patent offices to demand heightened standards of experimental evidence or disclosure in order to

\footnotetext{
176 R Jones, 'Three Things That Synthetic Biology Should Learn from Nanotechnology Soft Machines: Thoughts on the Future of Nanotechnology from Richard Jones' (2011), available at <http://www.softmachines.org > accessed 1 May 2013.

177 M Baker, (n 168) 404.

178 R Kwok, 'Five hard Truths for Synthetic Biology' (2010) 463 Nature 288.

179 M Baker, (n 168).

180 R Kwok (n 178).

181 Errors in disclosure for instance can be corrected by the person skilled in the art so long as there is no undue burden of experimentation. Synthon v SmithKline Beecham [2005] UKHL 59.

182 Conor Medsystems v Angiotech Pharmaceuticals 2008 UKHL 49.
} 
develop credibility markers. Such per se rules specific to particular technology sectors are, however, uncommon and controversial in patent law. ${ }^{183}$ Human gene therapy patent examination at the USPTO is a case in point where there is a presumption that the field itself is unpredictable. ${ }^{184}$ This presumption can be viewed as an innovation in management of complexity and uncertainty.

\section{CONCLUSION}

The institutional view of legal change and decision-making is ultimately a more realistic touchstone to evaluate the quality and coherence of patent law. Institutional features - opacity, stickiness and institutional complexity - in themselves would be remarkable because of the different ways in which they constrain decision-making in the patent system. The real analytical impact of these, however, unfolds due to the learning needs that are an integral aspect of the statutory framework of most patent regimes. Through habitual processes like choosing relevant prior art or setting the notional skill in the art or deciding on the multi-factorial inventive step, decisions are made under circumstances of uncertainty and complexity, both of which are likely to be exacerbated in the context of an emerging technology. In synthetic biology features of the technology show how unprecedented or uncertain circumstances can direct and determine outcomes of learning needs in the patent system.

A demonstrable insight of the institutional analysis presented here is the manner in which mechanistic processes drive much of legal change in patent law. In the absence of consensus on normative touchstones we can expect institutional features of the patent system to craft other, different, and for the large part unexpected, forms of legitimation. Many of the examples in this paper show an evolutionary direction to patent law towards content-less goals like certainty or mimesis. This sort of directed change is deeply problematic because of the possibility of incoherence of legal outcomes when considering the system as a whole.

In terms of substantive reform, an understanding of the institutional mechanics of legal change behoves commentators to stop asserting that patent law, if left to its own devices, will find the most optimal patentability standard or legal precept for assessing eligibility for patents. What is more likely to happen is that decisions made in response to learning needs expressed in opaque, sticky and institutionally complex patent systems lead to decisional outcomes that sacrifice substantive goals for short term gains in certainty and homogeneity.

183 A Devlin, 'Systemic Bias in Patent Law' (2011) 61 De Paul Law Review.

184 USPTO, Revised Interim Utility Guidelines Training Materials (1999) Example G. 